\title{
虚弱歯槽骨に対する高カルシウム食・カルシトニンの 併用療法に関する実験的研究
}

\author{
小 野 清一 郎 \\ 九州㐘科大学大学院歯学研究科小児菌科学専攻 (指導 : 木村光孝教授)
}

平成 6 年 12 月 26 日受理

\begin{abstract}
An Experimental Study on a Combined Treatment Method of a High-calcium Diet and Calcitonin on Alveolar Bone Debility

Seiichiro Ono
Department of Pediatric Dentistry (Director: Prof. Mitsutaka Kimura) Kyushu Dental College, Kitakyushu, Japan

Three-week-old male Wistar rats were maintained on a non-calcium diet or a low-calcium diet and bone debility was induced in them. Then the rats were given a high-calcium diet and eel calcitonin (ECT), and the effect on the alveolar bone was investigated.

The results were as follows:

1. Analysis of radiological bone shadow density

Al equivalence of the bone shadow density decreased in the order of the control group, the low-calcium diet, high-calcium diet and ECT group, the low-calcium diet and standard diet group, the non-calcium diet, high-calcium diet and ECT group.

2. Characteristic and quantitative analyses

In every group, the characteristic X-ray image showed higher density Ca than $\mathrm{P}$ in any individual trabeculae.

3. Light microscopic findings

As compared with the control group, higher bone absorption and higher decrease in bone quantity were observed in the non-calcium diet, high-calcium diet and ECT group and the low-calcium diet and standard diet group. In the low-calcium diet, high-calcium diet and ECT group, bone construction was accelerated highest next to the control group.

4. Scanning electron microscopic findings

As compared with the control group, wider expansion of bone marrow and more extensive bone absorption findings were observed in the non-calcium diet, high-calcium diet and ECT group and the low-calcium diet and standard diet group. The low-calcium diet, high-calcium diet and ECT group showed morphologically similar findings to those of the control group.

On the basis of the foregoing results, a combined treatment method of a high-calcium diet and calcitonin for alveolar bone debility has proved to accelerate remodeling in calcification of bone and bone construction. 
Key words : Alveolar bone debility/A high-calcium diet/A low-calcium $\operatorname{diet/ECT/~}$ Wistar rats

\section{緒 言}

成長期の小児，とくに低年齢児のカルシウムが欠乏す ると, 骨の形態的変化ならびに内部構造に大きな影響を 及ぼすことが, 当教室の一連の研究結果 ${ }^{1-27}$ から明らか

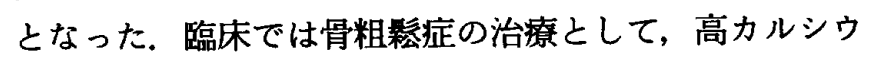
ム食やカルシウム代謝性因子であるカルシトニン, 活性 型ビタミン $\mathrm{D}_{3}$ などが応用されてきたが，いまだ研究者 によりその見解は一致していない.

虚弱骨に対する単独療法として, 高カルシウム食を用 いた陳 $(1989)^{1)}$ ，木村ら $(1989)^{2)}$, 黄本 $(1990)^{3)}$, 梅津 $(1991)^{4)}$, 中河原 $(1992)^{5)}$ ら，カルシトニンを用 いた橋本 $(1987)^{6)}$, 鯵坂 $(1988)^{7)}$, 新城 $(1988)^{8)}$,

木村 $(1991)^{9)}$ ら, 活性型ビタミン $\mathrm{D}_{3}$ を用いた井上 $(1988)^{10)}$ ，岩永 $(1989)^{11)}$ ，大倉 $(1990)^{12)}$ ，高野 $(1990)^{13)}$ らの報告がある. 併用療法としては, 加来 $(1992)^{14)}$ は高カルシウム食と活性型ビタミン $\mathrm{D}_{3}$ を用 い, 金城 $(1991)^{15)}$, 内野 $(1991)^{16)}$, 稲川 $(1992)^{17)}$, 木村ら (1992) ${ }^{18)}$ はカルシトニンと活性型ビタミン $\mathrm{D}_{3}$ を応用し、いずれも骨構築に対する効果を得たと報告し ている.

しかし、これらの実験をはじめ多くの研究 ${ }^{1-36)}$ に用い られたカルシウム久乏飼料や低カルシウム飼料のカルシ ウム含有率は, 標準飼料の $10 \%$ 未満という非常に低い 値で, in vivoの再現性に乏しいのが実情である.

このような流扎のなかで, 著者は臨床的立場から, 力
ルシゥム含有率を正常飼料の $30 \%$ まで高めた低カルシ ウム飼料に注目した。 そこで当教室用に配合された $30 \%$ 低カルシゥム飼料と従来のカルシゥム欠乏飼料で 惹起した虚弱骨に対して, 高カルシゥム飼料と骨吸收抑 制作用を持つウナギカルシトニン誘導体 (ECT) の併 用療法を応用した結果，いささかの知見を得たので報告 する。

\section{材料ならびに方法}

材料は生後 3 週齢のウィスター系雄ラット 40 匹を用 い, 無作為に次のような 4 群に分けた.

対照群 (標準食群)：ラット標準飼料（オリエンタル 醉母工業）と水道水で 6 週間飼育した.

カルシウム欠乏食·高カルシウム食· ECT 群 : A 食変 型カルシウム欠乏飼料（オリエンタル酵母工業）之蒸留 水で 3 週間飼育後, ラット標準飼料と牛骨粉（バイオク リーン) の重量比 $2: 1$ 混合飼料之水道水に切り換え 3 週間飼育しながら, ECT $0.2 \mathrm{U} / \mathrm{kg}$ 大腿後部に毎日筋 注した.

低カルシウム食・標準食群：A 食変型低カルシウム飼 料（オリエンタル酵母工業）と蒸留水で 3 週間飼育後, ラット標準飼料と水道水に切り換え 3 週間飼育した.

低カルシウム食·高カルシウム食·ECT 群 : A 食変型 低カルシウム飼料と蒸留水で 3 週間飼育後, ラット標準 飼料と牛骨粉の重量比 $2: 1$ 混合飼料之水道水に切り換 え 3 週間飼育しながら, ECTを $0.2 \mathrm{U} / \mathrm{kg}$ 大腿後部に毎

Table 1-1 Composition of experimental diets

(\%)

\begin{tabular}{l|c|c|c}
\hline \hline \multicolumn{1}{c|}{ Ingredients } & Normal diet & Non-Ca diet & Low-Ca diet \\
\hline$\beta$-corn starch & 38.00 & 38.00 & 37.64 \\
Vitamin-free casein & 25.00 & 25.00 & 25.00 \\
$\alpha$-potato starch & 10.00 & 10.00 & 10.00 \\
Cellulose powder & 8.00 & 8.00 & 8.00 \\
Soy bean oil & 6.00 & 6.00 & 6.00 \\
Mineral mixture & 6.00 & 6.00 & 6.00 \\
Granulated sugar & 5.00 & 5.00 & 5.00 \\
Vitamin mixture & 2.00 & 2.00 & 2.00 \\
CaCO $_{3}$ & 0.00 & 0.00 & 0.36 \\
\hline
\end{tabular}


Table 1-2 Composition of experimental diets

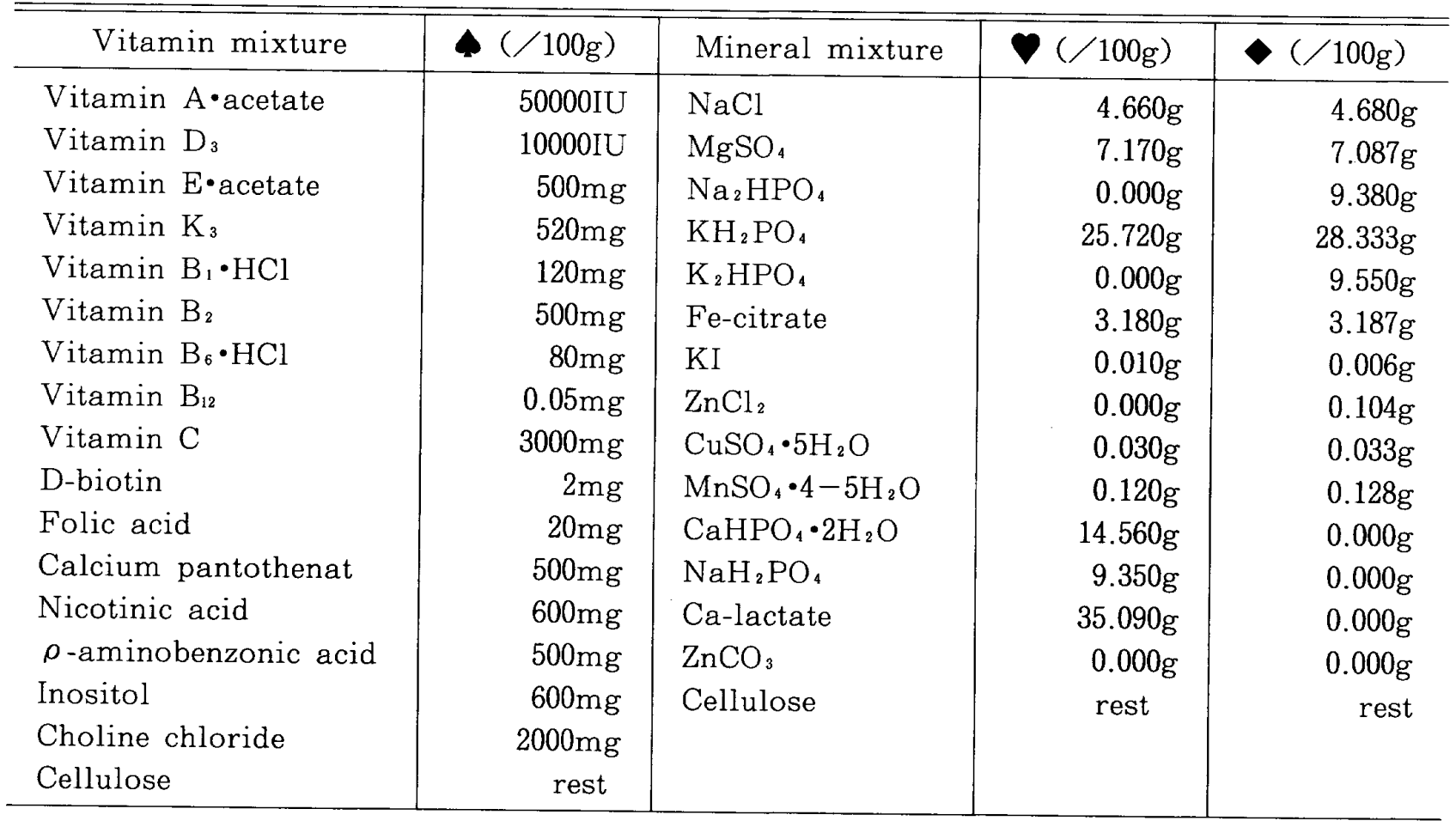

日筋注した。なお飼料については Table 1-1，2 に示 す通りである.

飼育中, 毎日定時に上血天秤で体重測定を行い, 飼育 完了後,イソゾール（吉富製薬）を腹腔内に注射し, 深 麻酔下にて屠殺した。直ちに頭部を採取し，10\%中性 ホルマリン液にて浸漬固定した. 固定後の頭部を正中で 分離し、ソフテックスタイプの撮影装置 (ESM-2, ソ フテックス）にて管電圧 $35 \mathrm{kVp}$, 管電流 $5 \mathrm{~mA}$, 撮影時 間 60 秒, 焦点皮虚間距離 $70 \mathrm{~cm}$ の条件下でアルミニゥム ステップを貼って軟 X 線撮影を行った。 さらにミクロ フォトメーター（PDS-15, コニカ）により, 高速ス リット幅 $10 \times 500 \mu \mathrm{m}$ でスキャニングパターンを描出 して光学的観察を行った.

次に定性・定量分析用試料で歯槽骨における Ca と P の分布状態を観察するために, エネルギー分散型 X 線 マイクロアナライザー（JED- 2000， 日本電子）を用い て定性·定量分析を行った.

また, $5 \%$ 硝酸脱灰後セロイジン包埋した光顕用試 料から, 下額霜槽骨の連続脱灰切片標本を $15 \mu \mathrm{m}$ の前 額断で作製し、へマトキシリン・エオジン重染色後鏡見 した.

さらに, 走查型電顕観察用試料から下顎骨を取り出 し, 切歯之雬槽骨を前額断で摘出してリン酸緩衝液 （pH 7.2）に浸漬しながら, 超音波洗浄器で洗浄してか
ら $2.5 \%$ グルタールアルデヒドで 1 時間浸清固定した. その後 $1 \%$ オスミック酸に $4{ }^{\circ} \mathrm{C}$ で約 2 時間浸漬し,さ らに上昇エタノール系列にて脱水した後, 2-メチル -2 一プロパノールを経て凍結乾燥装置（ID-2，エイコー エンジニアリング）で東結乾燥した。試料表面には，1 オンスパッタ（JFC-1100, 日本電子）用いて金蒸着を 行い, 走査型電子顕微鏡 (JSM $\mathrm{T}-300$, 日本電子) で 観察した.

\section{䊅 果}

\section{I. 体重}

実験開始時は全群平均体重 $40 \mathrm{~g}$ 前後だったが, 実験 1 週目に対照群は $62.54 \mathrm{~g}$ ，カルシゥム欠乏食・高カル シウム食・ECT 群は $68.67 \mathrm{~g}$, 低カルシウム食・標準食 群は $63.58 \mathrm{~g}$, 低カルシゥム食・高カルシゥム食・ECT 群は $71.58 \mathrm{~g}$ だった. 対照群とその他各群との平均值の 差の検定では, 低カルシゥム食·高カルシウム食·ECT 群の間に $1 \%$ ，カルシゥム欠乏食・高カルシゥム食 . ECT 群の間に $5 \%$ の危険率で有意差が認められ，対照 群が低値だった。

実験 2 週目に対照群は $119.94 \mathrm{~g}$ ，カルシウム欠乏食 高カルシゥム食·ECT 群は $87.39 \mathrm{~g}$, 低カルシゥム食. 標準食群は $113.23 \mathrm{~g}$, 低カルシウム食・高カルシウム 食・ECT 群は $116.91 \mathrm{~g}$ だった. 同様の検定では, カル 
シウム欠乏食・高カルシウム食・ECT 群の間に $1 \%$ の 危険率で有意差が認められ，対照群が高値だった。

実験 3 週目に対照群は $161.74 \mathrm{~g}$ ，カルシウム欠乏食. 高カルシウム食・ECT 群は $102.07 \mathrm{~g}$, 低カルシウム食· 標準食群は $136.00 \mathrm{~g}$, 低カルシゥム食・高カルシウム

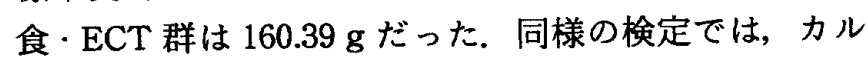
シウム欠乏食・高カルシウム食·ECT 群, 低カルシウム 食・標準食群の間に $1 \%$ の危険率で有意差が認められ, 対照群が高值だった。

実験 4 週目に対照群は $201.76 \mathrm{~g}$ ，カルシウム欠乏食 高カルシウム食·ECT 群は $155.84 \mathrm{~g}$, 低カルシウム食· 標準食群は $167.77 \mathrm{~g}$, 低カルシウム食・高カルシウム 食·ECT 群は $215.98 \mathrm{~g}$ だった. 同様の検定では, カル シウム久乏食·高カルシウム食·ECT 群, 低カルシウム 食・標準食群の間に $1 \%$ の危険率で有意差が認められ, 対照群が高値だった．低カルシウム食・高カルシウム 食·ECT 群の間に $5 \%$ の危険率で有意差が認められ, 対照群が低値だった。

実験 5 週目に対照群は $248.32 \mathrm{~g}$ ，カルシウム欠乏食・ 高カルシウム食·ECT 群は $218.38 \mathrm{~g}$, 低カルシウム食· 標準食群は $216.72 \mathrm{~g}$, 低カルシウム食・高カルシウム 食·ECT 群は $266.77 \mathrm{~g}$ だった. 同様の検定では, カル シウム欠乏食·高カルシウム食・ECT 群, 低カルシウム 食・標準食群の間に $1 \%$ の危険率で有意差が認められ, 対照群が高值だった。低カルシゥム食・高カルシウム 食·ECT 群の間に $1 \%$ の危険率で有意差が認められ, 対照群が低値だった。

実験 6 週目に対照群は $292.37 \mathrm{~g}$, カルシウム欠乏食・
高カルシウム食·ECT 群は $267.06 \mathrm{~g}$, 低カルシウム食· 標準食群は $256.09 \mathrm{~g}$, 低カルシウム食·高カルシウム


シゥム欠乏食·高カルシウム食·ECT 群, 低カルシウム 食・標準食群の間に $1 \%$ の危険率で有意差が認められ, 対照群が高值だった．低カルシウム食・高カルシウム 食·ECT 群の間に $5 \%$ の危険率で有意差が認められ, 対照群が低值だった（Table 2).

II. $\mathrm{X}$ 線学的所見

対照群の菡槽骨は, 骨梁が多く見られ, 配列は規則正 しく走行し, 厚さあ太く, ほぼ一定の厚みをあって切歯 の表面を被っていた（Fig. 1).

カルシウム欠乏食·高カルシウム食·ECT 群は, 対照 群の䨑槽骨に比べ細く, 骨梁の配列は不規則で, 厚さも 一定でなかった（Fig. 2).

低カルシゥム食・標準食群の䨑槽骨は, 対照群に比べ 骨梁が減少し，疎だったが，カルシウム欠乏食・高カル シウム食・ECT 群より規則的な配列だった（Fig. 3).

低カルシウム食・高カルシウム食・ECT 群の歯槽骨 は, 骨梁が増加し, 配列もかなり規則的で, 厚さも増加 していた (Fig. 4).

\section{X 線学的骨密度（骨塩量）}

骨密度の平均 $\mathrm{Al}$ 当量は, 対照群が $1.94 \mathrm{~mm}$, カルシウ ム欠乏食・高カルシウム食・ECT 群が $0.69 \mathrm{~mm}$, 低カル シウム食・標準食群が $0.55 \mathrm{~mm}$, 低カルシウム食・高カル

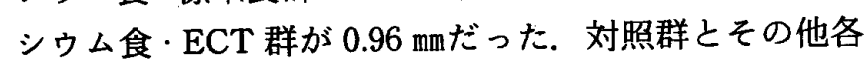
群との平均値の差の検定では, 全て $1 \%$ の危険率で有 意差が認められ，対照群が高値だった（Table 3).

Table 2 Body weight between the control group and each experimental group

(g)

\begin{tabular}{c|c|c|c|c|c|c|c|c}
\hline \hline \multirow{2}{*}{ Group } & \multicolumn{2}{|c|}{} & \multicolumn{2}{c|}{$\begin{array}{l}\text { Non-Ca diet, } \\
\text { high-Ca diet } \\
\text { and ECT group }\end{array}$} & \multicolumn{2}{|c|}{$\begin{array}{l}\text { Low-Ca diet } \\
\text { and standard } \\
\text { diet group }\end{array}$} & \multicolumn{2}{c}{$\begin{array}{l}\text { Low-Ca diet, } \\
\text { high-Ca diet } \\
\text { and ECT group }\end{array}$} \\
\cline { 2 - 10 } Date & Mean & S.D. & Mean & S.D. & Mean & S.D. & Mean & S.D. \\
\hline Pre-ex. & 38.43 & 3.85 & 40.40 & 1.36 & 37.33 & 2.77 & 40.18 & 2.26 \\
7th day & 62.54 & 5.69 & $68.67^{*}$ & 4.68 & 63.58 & 2.80 & $71.58^{* *}$ & 5.17 \\
14th day & 119.94 & 7.26 & $87.39^{* *}$ & 6.09 & 113.23 & 6.87 & 116.91 & 10.26 \\
21st day & 161.74 & 9.98 & $102.07^{* *}$ & 6.41 & $136.00^{* *}$ & 15.08 & 160.39 & 10.23 \\
28th day & 201.76 & 13.94 & $155.84^{* *}$ & 7.43 & $167.77^{* *}$ & 12.30 & $215.98^{*}$ & 10.84 \\
35th day & 248.32 & 14.00 & $218.38^{* *}$ & 11.53 & $216.72^{* *}$ & 13.78 & $266.77^{* *}$ & 12.80 \\
42nd day & 292.37 & 11.45 & $267.06^{* *}$ & 17.55 & $256.09^{* *}$ & 14.49 & $309.72^{*}$ & 11.84 \\
\hline
\end{tabular}




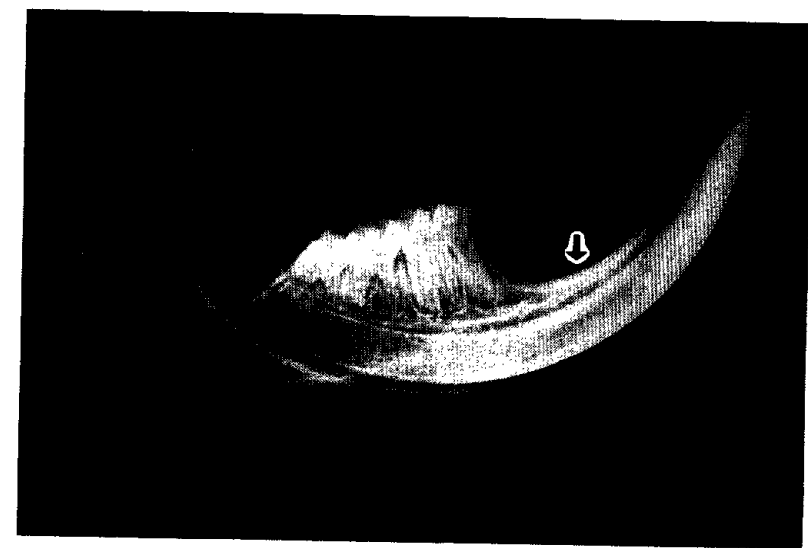

Fig. 1 Radiogram of the 6 th week. Control group Arrow : Alveolar bone



Fig. 2 Radiogram of the 6 th week. Non-Ca diet, high-Ca diet and ECT group Arrow: Alveolar bone

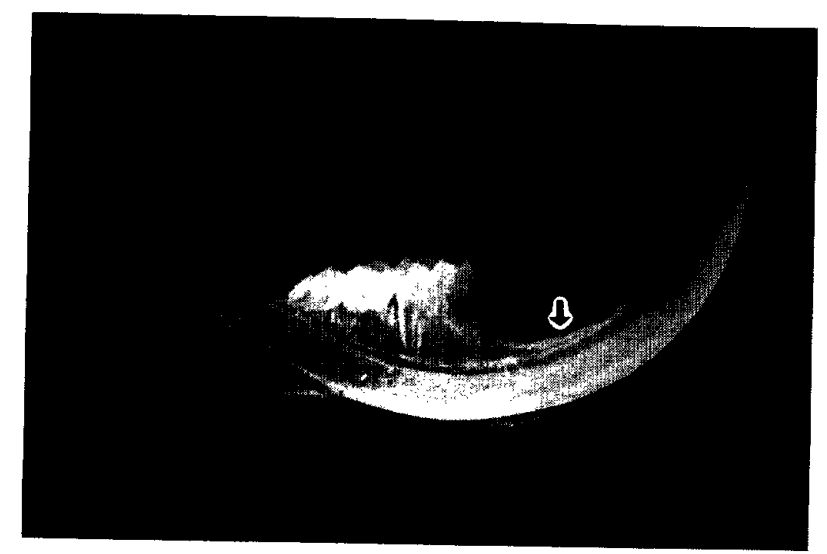

Fig. 3 Radiogram of the 6 th week. Low-Ca diet, standard diet group Arrow : Alveolar bone

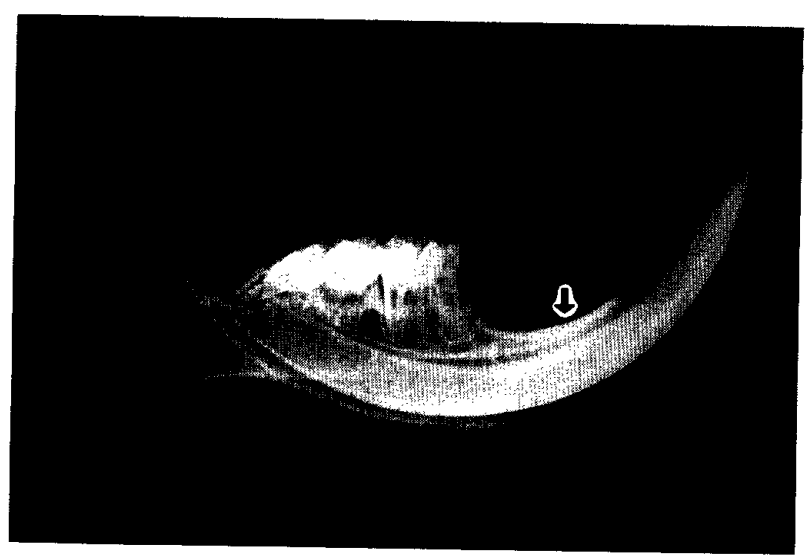

Fig. 4 Radiogram of the 6 th week. Low-Ca diet, high-Ca diet and ECT group Arrow : Alveolar bone

Table 3 Bone shadow density between the control group and each experimental group

\begin{tabular}{c|l|l}
\hline \multicolumn{1}{c|}{ Group } & \multicolumn{1}{c}{$(\mathrm{mm})$} \\
\hline Control group & 1.94 & 0.36 \\
Non-Ca diet,high-Ca diet and ECT group & $0.69^{* *}$ & 0.15 \\
Low-Ca diet and standard diet group & $0.55^{* *}$ & 0.07 \\
Low-Ca diet,high-Ca diet and ECT group & $0.96^{* *}$ & 0.17 \\
\hline & & $* * \mathrm{p}<0.01$ \\
& & ${ }^{*} \mathrm{p}<0.05$
\end{tabular}

IV. 定性·定量分析所見

$\mathrm{X}$ 線マイクロアナライザーによる面分析で, 対照群 の $\mathrm{Ca}$ の特性 $\mathrm{X}$ 線像の濃度は, 同一骨梁の範囲内では $\mathrm{P}$ より高かった（Fig. 5-a, b ). その他の群でも同様
の所見が認められた (Fig. 6-8).

点分析での $\mathrm{Ca}$ の占める割合の平均は, 対照群が $66.78 \%$ ，カルシゥム欠乏食・高カルシゥム食・ECT 群 が $67.09 \%$, 低カルシゥム食・標準食群が $66.14 \%$, 低カ 


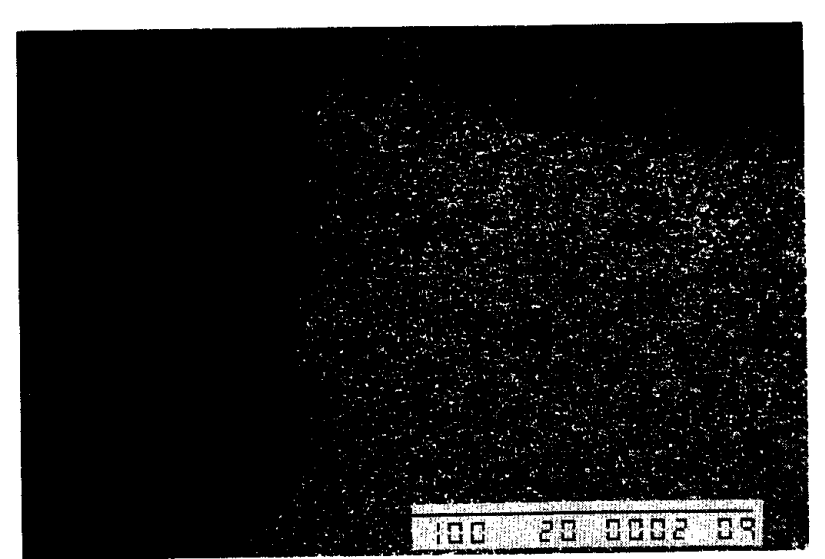

Fig. 5-a Ca characteristic $\mathrm{X}$-ray images of alveolar bone.

Control group

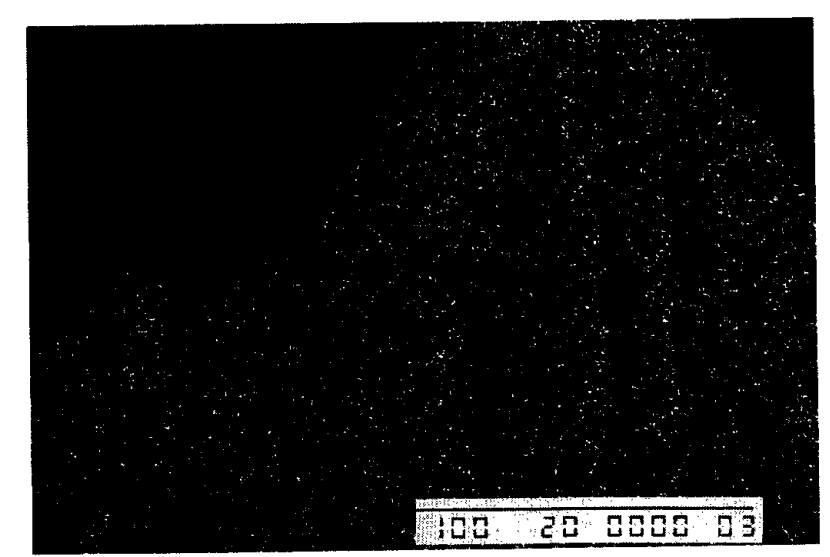

Fig. 6-a Ca characteristic X-ray images of alveolar bone.

Non-Ca diet, high-Ca diet and ECT group

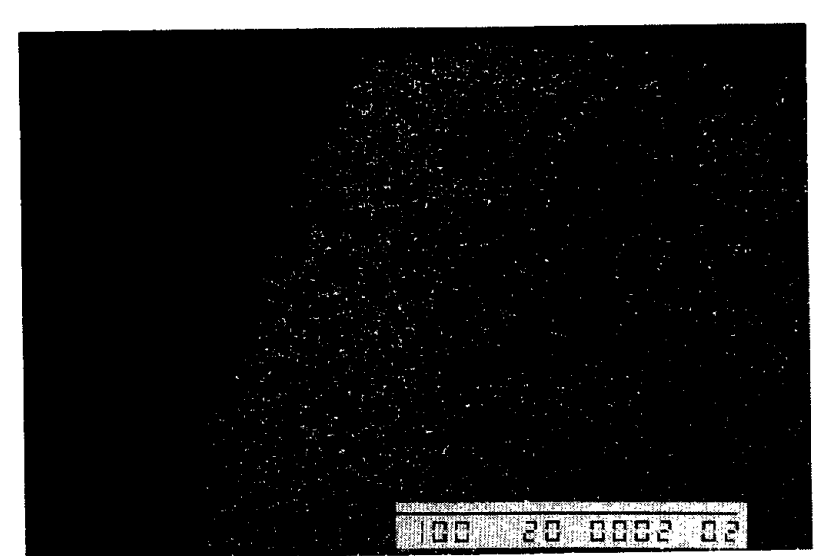

Fig. 7-a Ca characteristic X-ray images of alveolar bone.

Low-Ca diet and standard diet group

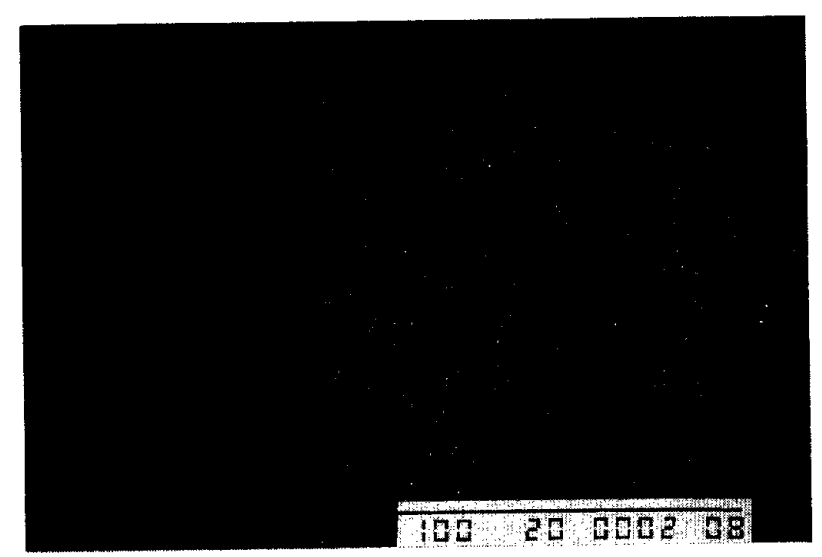

Fig. 5-b $\mathrm{P}$ characteristic $\mathrm{X}$-ray images of alveolar bone.

Control group

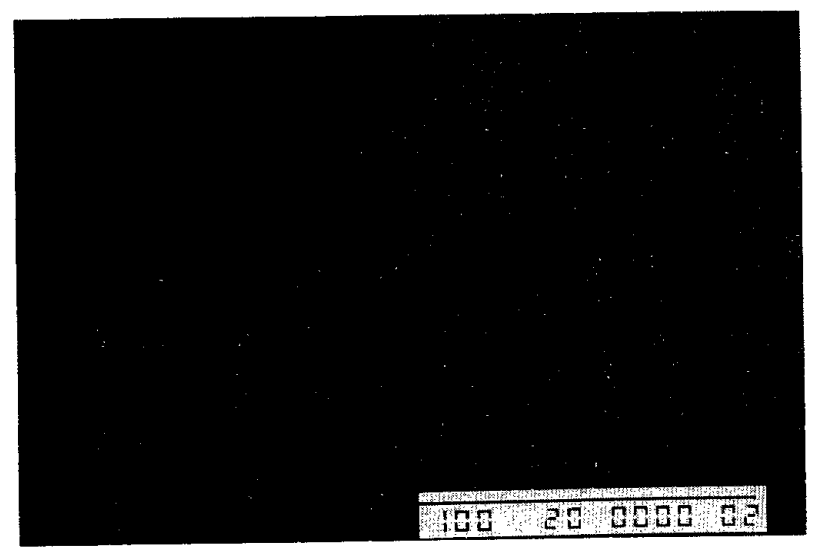

Fig. 6-b P characteristic X-ray images of alveolar bone.

Non-Ca diet, high-Ca diet and ECT group

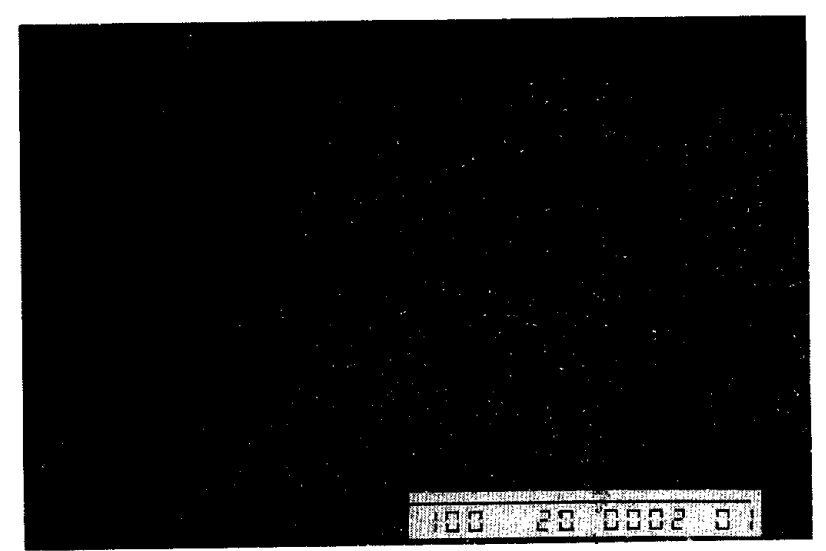

Fig. 7-b P characteristic $\mathrm{X}$-ray images of alveolar bone.

Low-Ca diet and standard diet group 


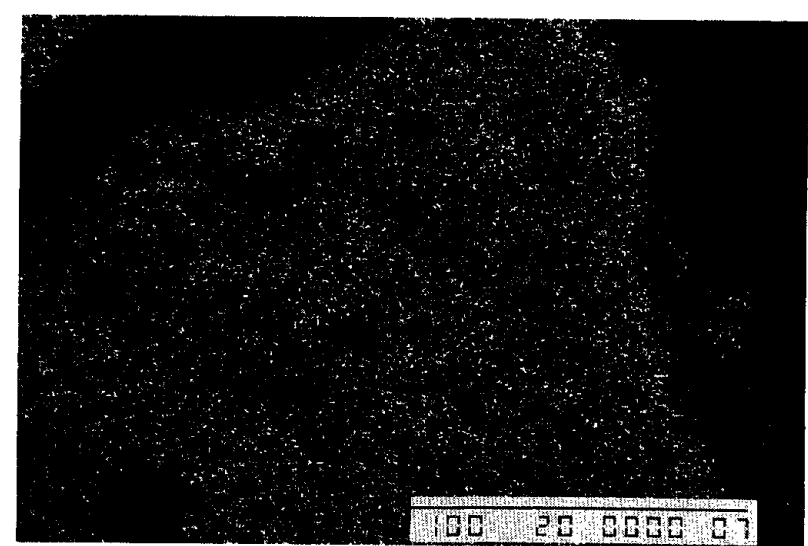

Fig. 8-a Ca characteristic X-ray images of alveolar bone.

Low-Ca diet, high-Ca diet and ECT group

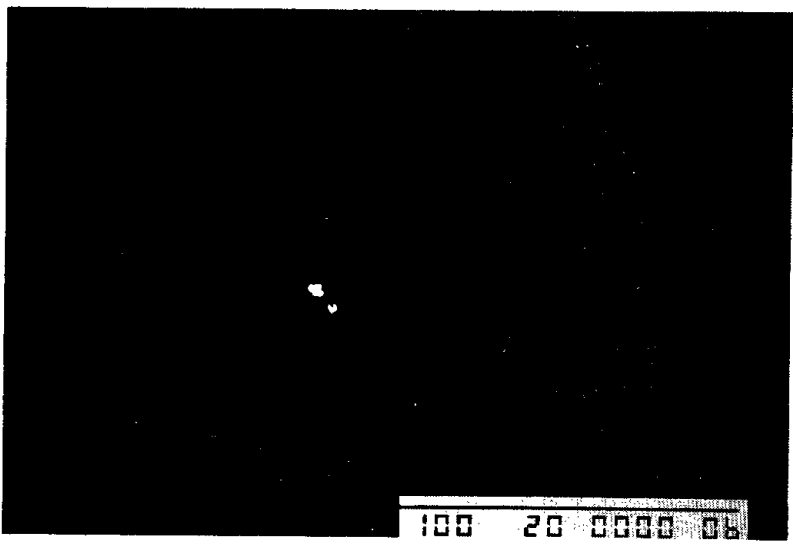

Fig. 8-b P characteristic X-ray images of alveolar bone.

Low-Ca diet, high-Ca diet and ECT group

Table 4 Analysis of $\mathrm{Ca}$ and $\mathrm{P}$ of alveolar bone by X-ray microanalyzer

\begin{tabular}{|c|c|c|c|c|}
\hline \multirow[t]{2}{*}{ Element } & \multicolumn{2}{|c|}{$\mathrm{Ca}$} & \multicolumn{2}{|c|}{$\mathrm{P}$} \\
\hline & Mean & S.D. & Mean & S.D. \\
\hline Control group & 66.78 & 0.78 & 33.22 & 0.78 \\
\hline Non-Ca diet,high-Ca diet and ECT group & 67.09 & 3.97 & 32.91 & 3.97 \\
\hline Low-Ca diet and standard diet group & 66.14 & 3.94 & 33.79 & 3.83 \\
\hline Low-Ca diet,high-Ca diet and ECT group & 64.51 & 2.98 & 35.49 & 2.98 \\
\hline
\end{tabular}

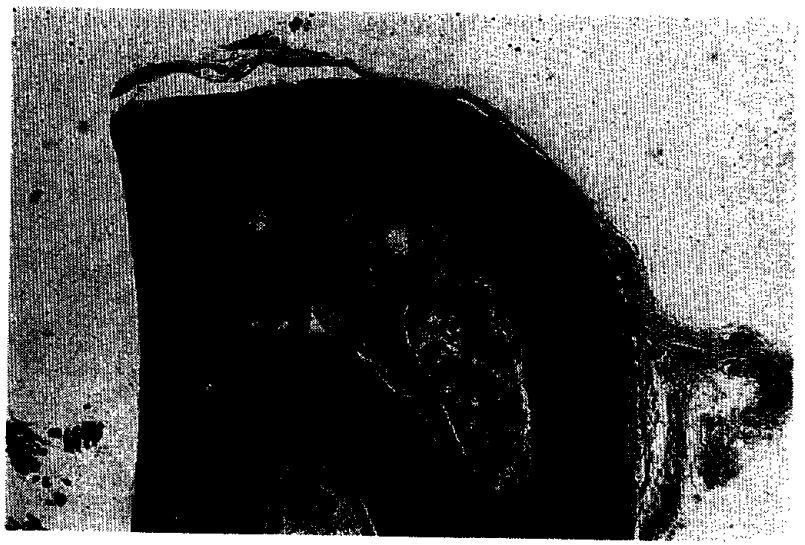

Fig. 9 Alveolar bone of the 6 th week. Control group $\mathrm{H} \cdot \mathrm{E}$ stain

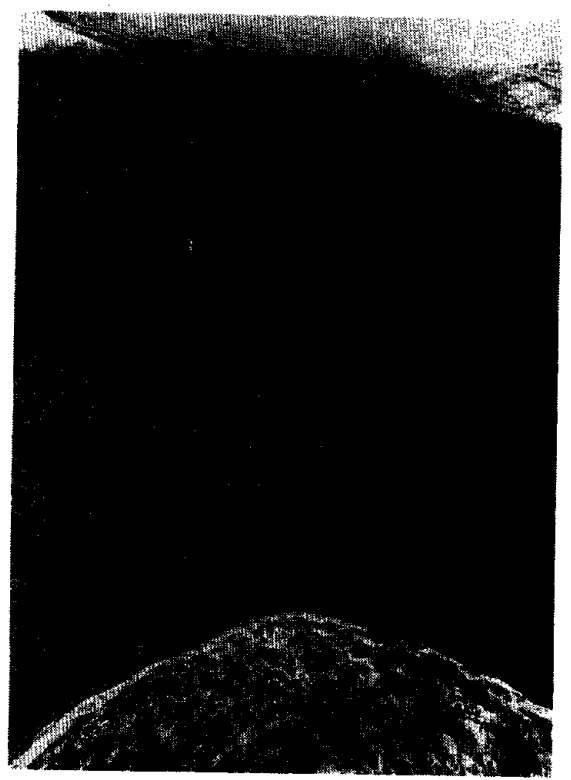

Fig. 10 A higher magnification of Fig. 9. $\mathrm{H} \cdot \mathrm{E}$ stain $(\times 100)$ 
ルシウム食・高カルシウム食・ECT 群が $64.51 \%$ だっ た. 対照群とその他各群との平均値の差の検定では, 有 意差は認められなかった，Pでは，対照群が $33.22 \%$, カルシウム欠乏食・高カルシウム食・ECT 群が 32.91\%, 低カルシウム食・標準食群が $33.79 \%$ ，低カルシウム食・ 高カルシウム食·ECT 群が 35.49\%, 同様の検定では, 有意差は認められなかった（Table 4).

V. 光学顕微鏡所見

\section{A. 対照群}

下顎第一曰蒌前方 $3 \mathrm{~mm}$ の部の前額断組織像を観察し た. 観察部は, 切歯と雬根膜線維で結ばれている茵槽骨 と, エナメル器が存在し血管を含有した蹯性結合組織に 対応している歯槽骨だった．前者は構造が異なる二種類 の骨組織からなっていた，歯根膜に接する部分は，歯根 膜のシャーピー線維束で柵状に貫かれている線維骨から

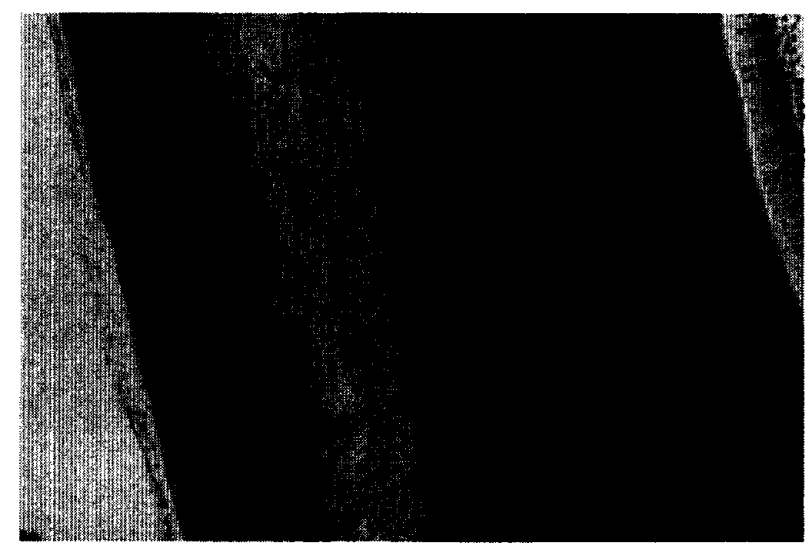

Fig. 11 A higher magnification of Fig. 9 . $\mathrm{H} \cdot \mathrm{E}$ stain

$(\times 100)$

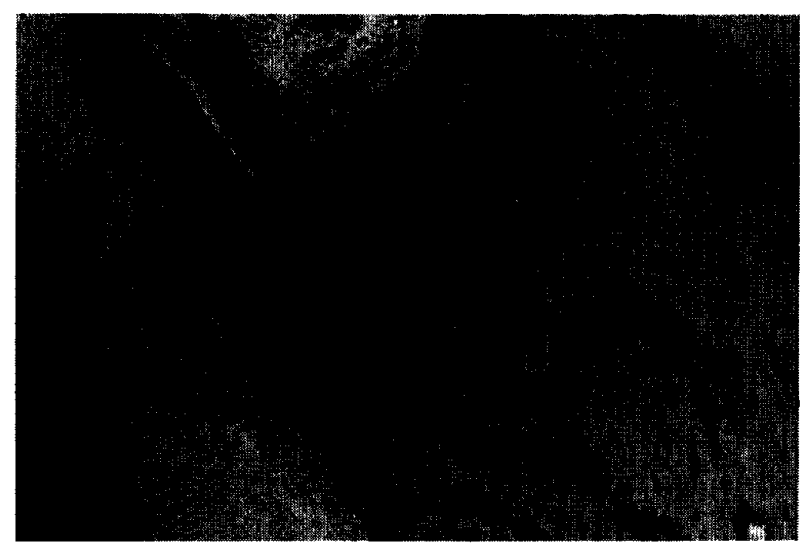

Fig. 12 A higher magnification of Fig. 9 . $\mathrm{H} \cdot \mathrm{E}$ stain $(\times 100)$
なっており，ハバース管はほとんどなく，骨小腔は整然 と並んでいた，大小の骨髄を囲む部分は，層板状を呈 し，最表層では緻密骨としての基質面に，骨小腔が整然 と配列していた，緻密骨の範囲は広く，海綿骨とほぼス ムーズに癒合していた（Fig. 9，10）。また，中心側表 面では骨芽細胞が認められ，外側では鋸歯状の骨吸収像 が認められた（Fig. 11，12). 後者は, エナメル器が存 在し血管を含有した疎性結合組織によって占められてい る中心側部と外側部が連続し，中央で厚い歯槽骨を形成 していた（Fig. 13，14）.

B. カルシウム欠乏食·高カルシウム食· ECT 群 線維骨が多量に消失し，骨䯣が拡大し，大幅な骨量の 減少が認められた（Fig. 15，16）。 中心側や外側の歯槽 骨ではハバース管を中心とした同心円状の層板構造が認 められたが，骨小腔は少なく表面の骨芽細胞は認められ



Fig. 13 Alveolar bone of the 6 th week. Control group

$\mathrm{H} \cdot \mathrm{E}$ stain

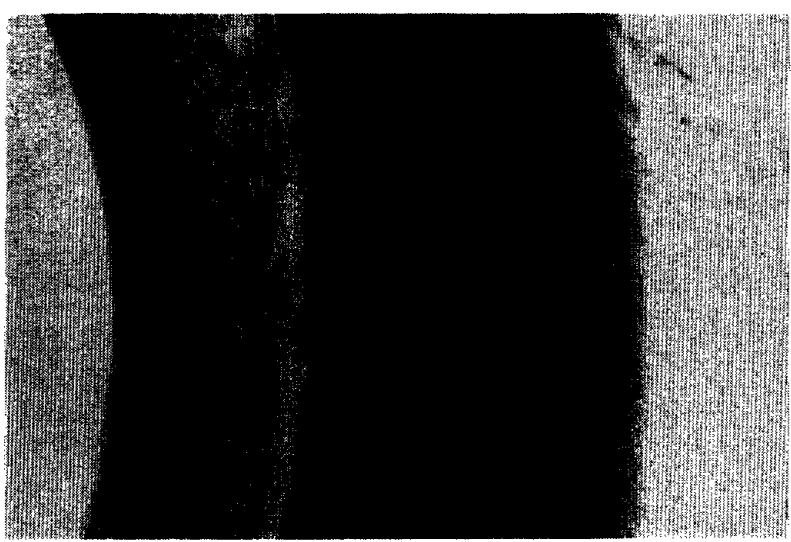

Fig. 14 A higher magnification of Fig. 13. $\mathrm{H} \cdot \mathrm{E}$ stain $(\times 100)$ 
なかった（Fig. 17，18），一方エナメル器に対応する㐘 槽骨では結合織の占める割合が多く, 骨量の隇少が顕著 だった．層板構造は認められなかった（Fig. 19）.

C. 低カルシウム食・標準食群

カルシウム欠乏食・高カルシウム食・ECT 群と同様の 骨吸収所見を呈し，歯根膜に接する線維骨は認められな かったが，骨䯣を囲む骨層の増加も見られ，歯根膜の シャーピー線維束は不規則に新生骨層を貫き，ハバース 系が存在した（Fig. 20，21），中心側表面には骨芽細胞 が認められ，外側ではハバース系皇認められた（Fig. 22，23)。一方エナメル器に対応する霜槽骨では骨量の 増加が見られた（Fig. 24，25）。

D. 低カルシウム食·高カルシウム食・ECT 群

低カルシゥム食・標準食群に比へ厚く, 骨䯣も更に減 少し，歯根膜に接する骨層はより增加していた，骨䯣を 囲む骨層は緻密になっていた。ハバニス系は更に増加

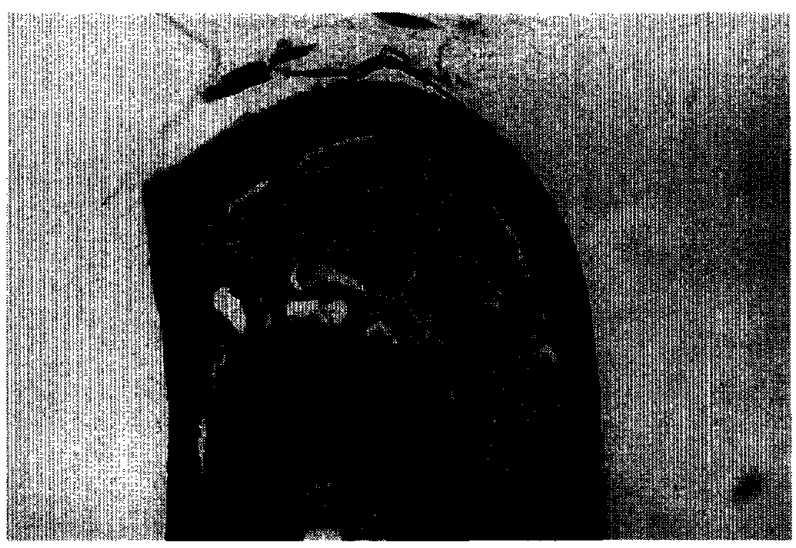

Fig. 15 Alveolar bone of the 6 th week. Non-Ca diet, high-Ca diet and ECT group $\mathrm{H} \cdot \mathrm{E}$ stain

$(\times 20)$

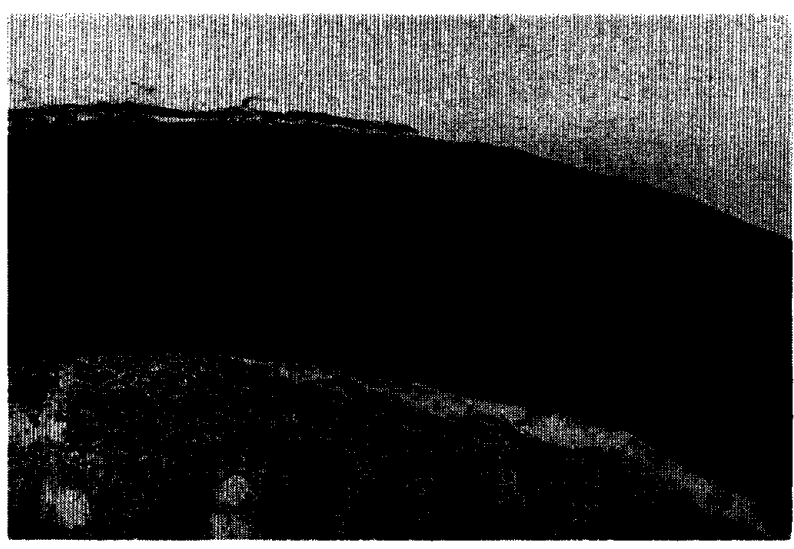

Fig. 16 A higher magnification of Fig. 15. $\mathrm{H} \cdot \mathrm{E}$ stain $(\times 100)$

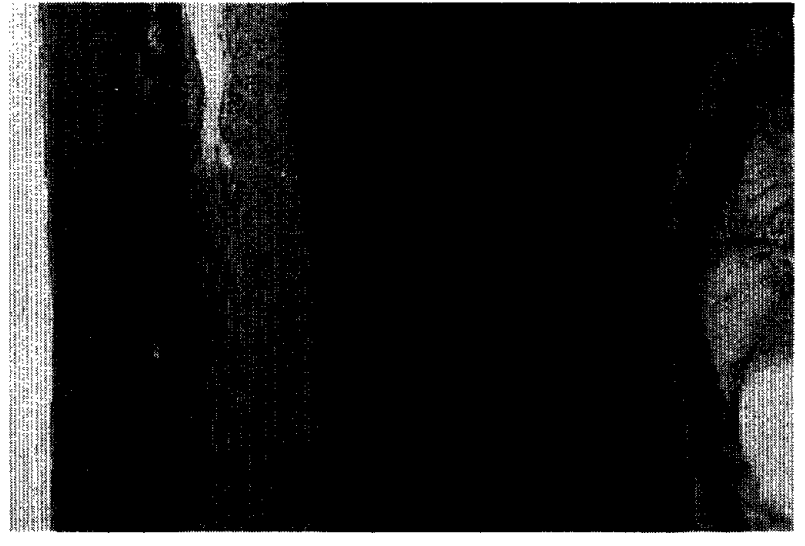

Fig. 17 A higher magnification of Fig. 15. $\mathrm{H} \cdot \mathrm{E}$ stain

$(\times 100)$

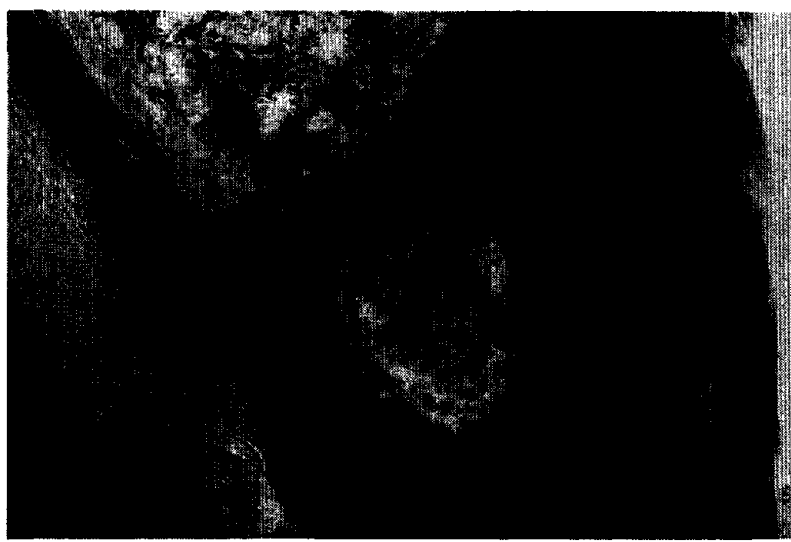

Fig. 18 A higher magnification of Fig. 15. $\mathrm{H} \cdot \mathrm{E}$ stain

$(\times 100)$

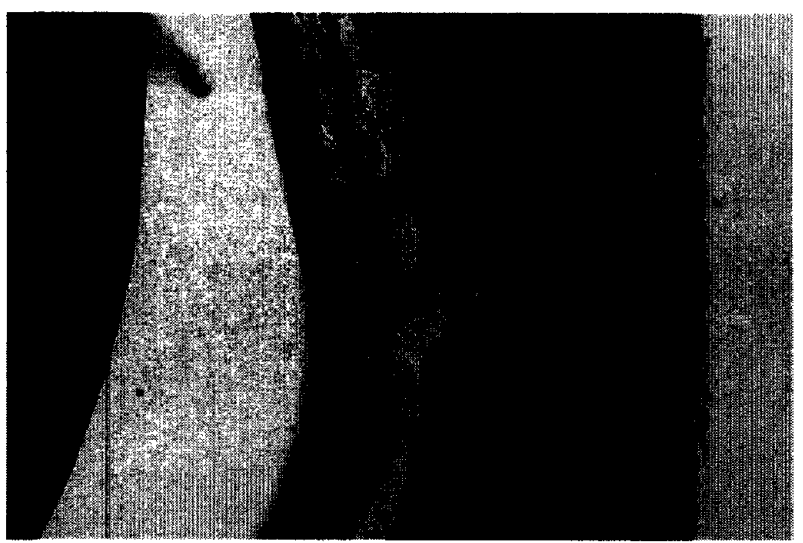

Fig. 19 Alveolar bone of the 6 th week. Non-Ca diet, high-Ca diet and ECT group $\mathrm{H} \cdot \mathrm{E}$ stain

$(\times 100)$ 


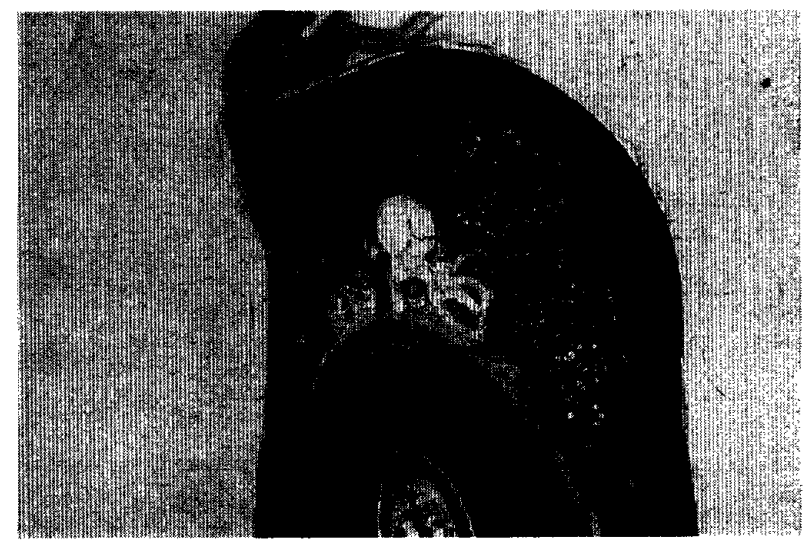

Fig. 20 Alveolar bone of the 6 th week. Low-Ca diet and standard diet group $\mathrm{H} \cdot \mathrm{E}$ stain

$(\times 20)$



Fig. 21 A higher magnification of Fig. 20. $\mathrm{H} \cdot \mathrm{E}$ stain

$(\times 100)$

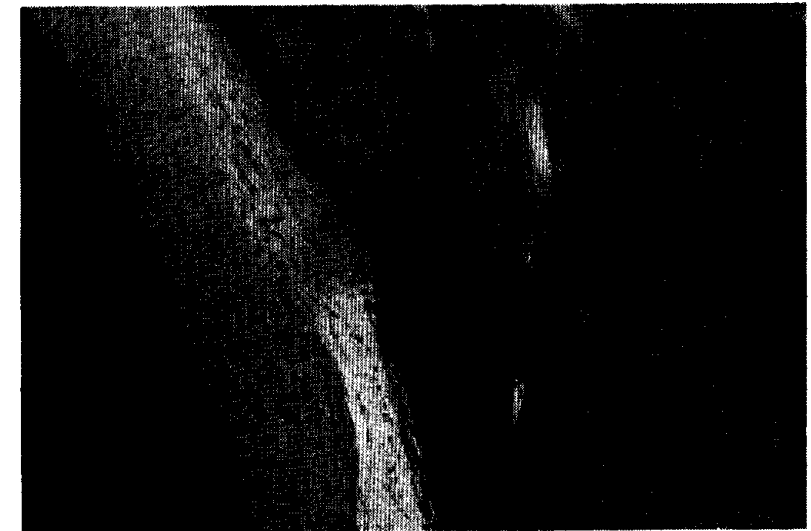

Fig. 23 A higher magnification of Fig. 20. $\mathrm{H} \cdot \mathrm{E}$ stain

$(\times 100)$

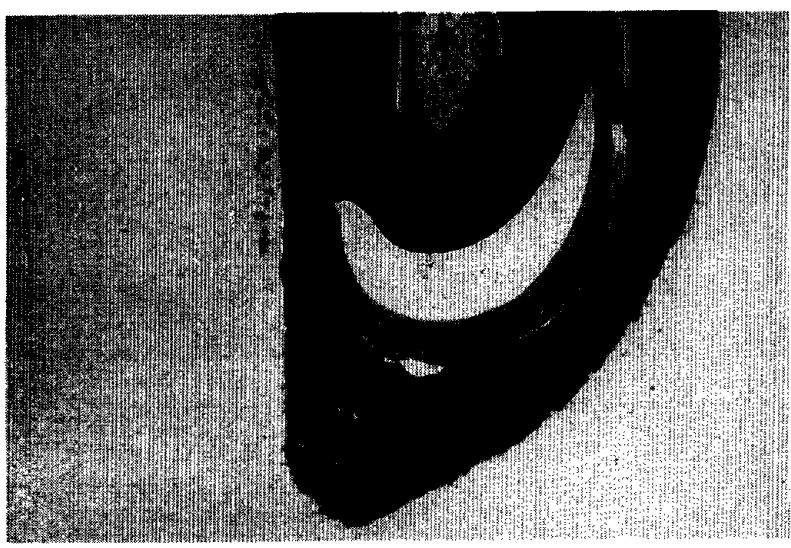

Fig. 24 Alveolar bone of the 6 th week.

Low-Ca diet and standard diet group $\mathrm{H} \cdot \mathrm{E}$ stain

$(\times 20)$

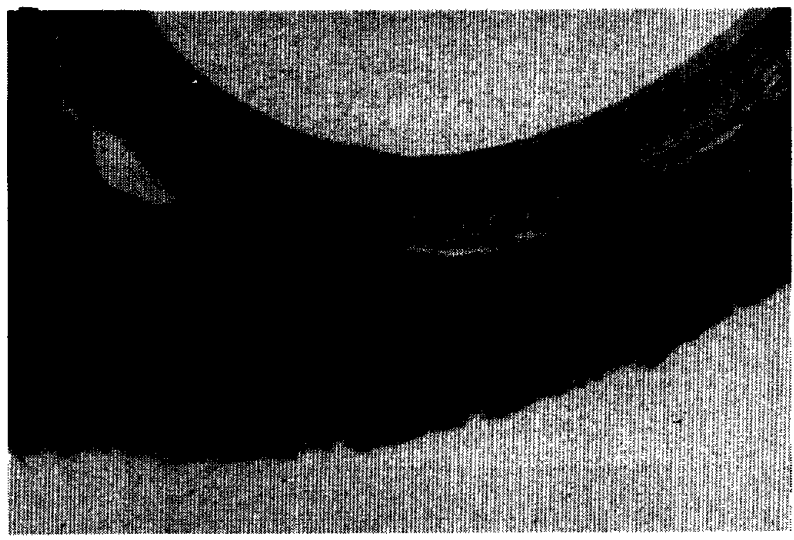

Fig. 25 A higher magnification of Fig. 24.

$\mathrm{H} \cdot \mathrm{E}$ stain $(\times 100)$
Fig. 22 A higher magnification of Fig. 20. $\mathrm{H} \cdot \mathrm{E}$ stain $(\times 100)$ 
し，骨小腔は規則的に配列していた（Fig. 26，27）。中 心側の歯槽骨は厚く，規則的に配列した骨小腔が多く認 められ，外側ではハバース系が存在し鋸歯状の吸収像も 見られた（Fig. 28，29)。一方ェナメル器に対応する歯 槽骨でも骨量が増加したのが認められた（Fig. 30).

VI. 走查型電子顕微鏡所見

対照群は，歯槽骨の全体が緻密に形成され骨䯣腔が少 なく，厚く太い骨層を有していた（Fig. 31），骨首の表 面のコラーゲン原線維束の走行は一定方向で，その表面 にはコラーゲン原線維網が多量に認められた（Fig. $32)$.

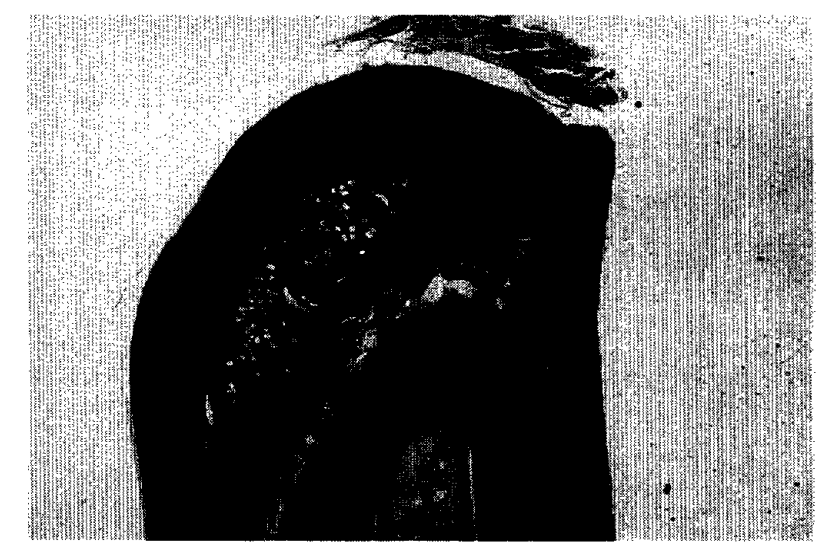

Fig. 26 Alveolar bone of the 6 th week. Low-Ca diet, high-Ca diet and ECT group $\mathrm{H} \cdot \mathrm{E}$ stain $(\times 20)$

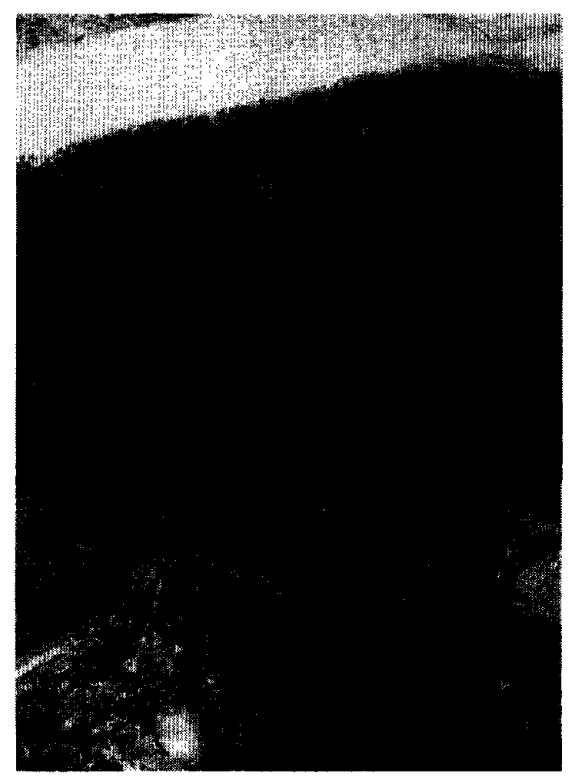

Fig. 27 A higher magnification of Fig. 26. $\mathrm{H} \cdot \mathrm{E}$ stain

$(\times 100)$

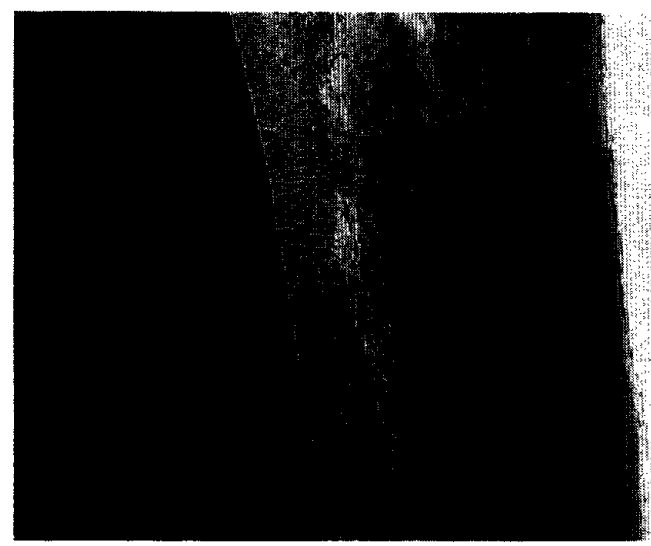

Fig. 28 A higher magnification of Fig. 26. $\mathrm{H} \cdot \mathrm{E}$ stain

$(\times 100)$

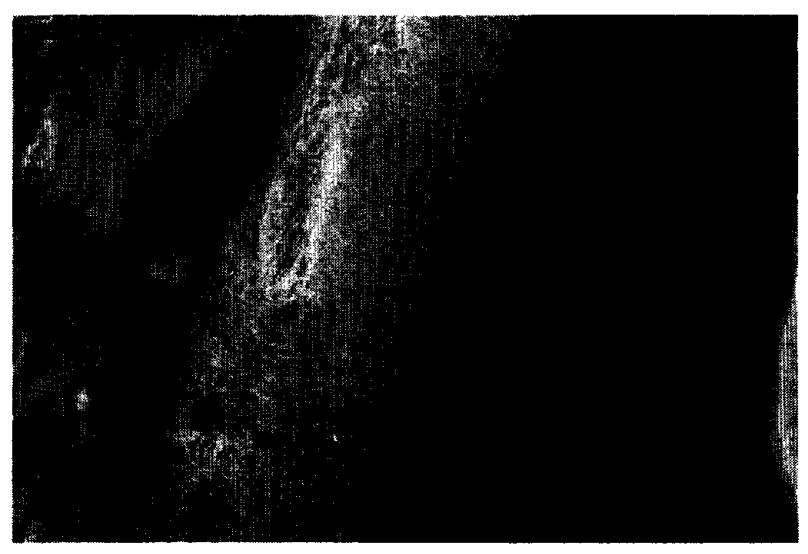

Fig. 29 A higher magnification of Fig. 26. $\mathrm{H} \cdot \mathrm{E}$ stain

$(\times 100)$

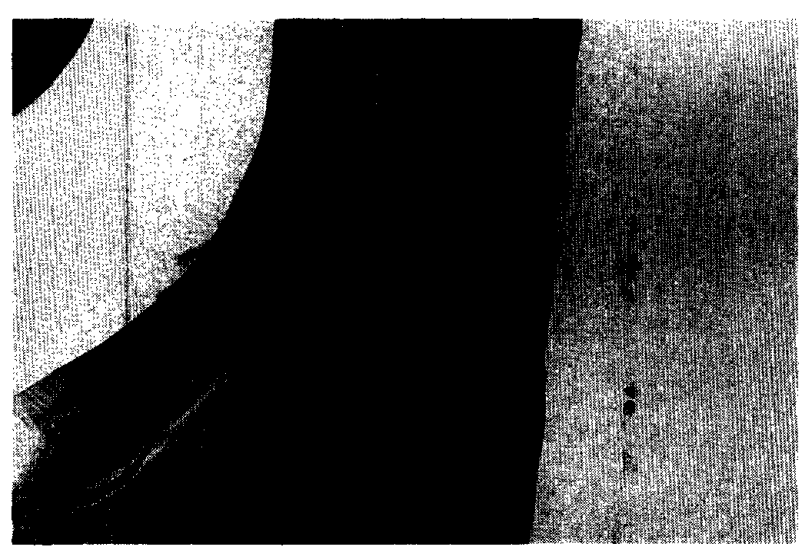

Fig. 30 Alveolar bone of the 6 th week. Low-Ca diet, high-Ca diet and ECT group $\mathrm{H} \cdot \mathrm{E}$ stain $(\times 100)$ 
カルシゥム欠乏食・高カルシゥム食·ECT 群の歯槽骨 の全体像は小さく，骨髄腔が多く存在し，非常に低い骨 構築が認められた (Fig. 33)。骨層の一部に吸収所見が 広範に見られ，その表面は疎で不規則な走行のコラーゲ ン原線維網で覆われ不定形の骨小腔も存在した（Fig. 34).

低カルシウム食·標準食群は, カルシウム欠乏食・高 カルシウム食·ECT 群に比べ, 歯槽骨の全体像は厚く, 均一に緻密化の傾向を示し, 骨䯣腔が減少していた

(Fig. 35)。骨層の一部には吸収像が認められ，露出し た浅い骨小肤も存在し，その表面はコラーゲン原線維網 によって覆われているのが観察されたが, 対照群に比べ てその走行は不規則で蹯だった（Fig. 36).

低カルシウム食·高カルシゥム食·ECT 群は, 低カル シゥム食・標準食群に比べ, 骨層全体はさらに厚くな り，均一に緻密化の傾向を示し，より高い骨構築が認め られた（Fig. 37)，骨層の一部には多量のコラーゲン原 線維束やコラーゲン原線維網が規則的に走行しているの が観察された（Fig. 38）.

VII. 血液所見

A. 電解質検査

1. 血清 $\mathrm{Ca}$

対照群の平均血清 $\mathrm{Ca}$ 值は $10.38 \mathrm{mg} / \mathrm{dl}$, カルシゥム 欠乏食・高カルシウム食・ECT 群は $10.36 \mathrm{mg} / \mathrm{dl}$, 低力 ルシゥム食・標準食群は $10.53 \mathrm{mg} / \mathrm{dl}$, 低カルシウム食·

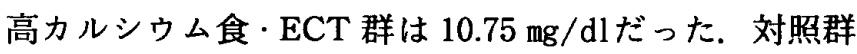
とその他各群との平均值の差の検定では, 低カルシウム 食·高カルシゥム食·ECT 群の間に $1 \%$ の危険率で有 意差が認められ，対照群が低值だった。

\section{2. 血清 $P$}

対照群の平均血清 $\mathrm{P}$ 值は $7.66 \mathrm{mg} / \mathrm{dl}$, カルシゥム欠乏 食·高カルシゥム食・ECT 群は $8.90 \mathrm{mg} / \mathrm{dl}$, 低カルシウ ム食・標準食群は $8.88 \mathrm{mg} / \mathrm{dl}$, 低カルシウム食・高カル シゥム食·ECT 群は $10.20 \mathrm{mg} / \mathrm{d} 1$ だった．同様の検定で は, 全て $1 \%$ の危険率で有意差が認められ, 対照群が 低値だった。

3. 血清 $\mathrm{Ca}$ と血清 $P$ の比

血清 $\mathrm{Ca}$ と血清 P の比の平均値は対照群が 1.36 , カル シゥム欠乏食・高カルシゥム食・ECT 群は 1.19 , 低カル シウム食·標準食群は 1.19 , 低カルシゥム食・高カルシ ウム食·ECT群は 1.06 だった，同様の検定では，全て $1 \%$ の危険率で有意差が認められ, 対照群が高值だっ た.

4. 血清 $\mathrm{Na}$
対照群の平均血清 $\mathrm{Na}$ 值は $142.88 \mathrm{mEq} / \ell$, カルシウ ム欠乏食・高カルシゥム食・ECT 群は $141.25 \mathrm{mEq} / \ell$, 低カルシゥム食・標準食群は $145.13 \mathrm{mEq} / \ell$, 低カルシ ウム食·高カルシゥム食·ECT 群は $141.75 \mathrm{mEq} / \ell$ だっ た. 同様の検定では，カルシゥム欠乏食·高カルシゥム 食·ECT 群の間に $5 \%$ の危険率で有意差が認められ, 対照群が高値だった．低カルシゥム食・標準食群の間に $1 \%$ の危険率で有意差が認められ，対照群が低值だっ た.

\section{5. 血清 $K$}

対照群の平均血清 $\mathrm{K}$ 值は $5.10 \mathrm{mEq} / \ell$, カルシゥム欠 乏食·高カルシゥム食·ECT 群は $5.74 \mathrm{mEq} / \ell$, 低カル シゥム食・標準食群は $5.60 \mathrm{mEq} / \ell$, 低カルシウム食· 高カルシゥム食·ECT 群は $5.51 \mathrm{mEq} / \ell$ だった．同様の 検定では, 全て $5 \%$ の危険率で有意差が認められ, 対 照群が低値だった。

6. 血清 $\mathrm{Cl}$

対照群の平均血清 $\mathrm{Cl}$ 值は $102.88 \mathrm{mEq} / \ell$ ，カルシウ ム欠乏食·高カルシゥム食·ECT 群は $103.63 \mathrm{mEq} / \ell$, 低カルシウム食・標準食群は $102.63 \mathrm{mEq} / \mathrm{l}$, 低カルシ ウム食・高カルシゥム食・ECT 群は $100.25 \mathrm{mEq} / \ell$ だっ た. 同様の検定では, 低カルシゥム食・高カルシゥム 食·ECT 群の間に $1 \%$ の危険率で有意差が認められ, 対照群が高值だった（Table 5).

B. 生化学検查

1. GOT

対照群の平均 GOT 值は144.38U，カルシゥム欠乏 食·高カルシゥム食·ECT 群は199.88U, 低カルシウム 食·標準食群は241.75U, 低カルシウム食・高カルシウ 么食・ECT 群は $182.25 U$ だった。対照群とその他各群 との平均値の差の検定では, 全て $1 \%$ の危険率で有意 差が認められ, 対照群が低値だった。

2. GPT

対照群の平均 GPT 值は $32.38 \mathrm{U}$ ，カルシウム欠乏食· 高カルシウム食·ECT 群は41.88U, 低カルシゥム食· 標準食群は43.13U, 低カルシウム食·高カルシウム食· ECT 群は35.88U だった．同様の検定では，カルシゥム 欠乏食·高カルシウム食·ECT 群, 低カルシウム食·標 準食群の間に $1 \%$ の危険率で有意差が認められ, 対照 群が低值だった。

3. $\mathrm{LDH}$

対照群の平均 LDH 值は1004.38U, カルシゥム欠乏 食·高カルシゥム食·ECT 群は1174.75U, 低カルシウ ム食·標準食群は2396.25U, 低カルシゥム食・高カルシ 


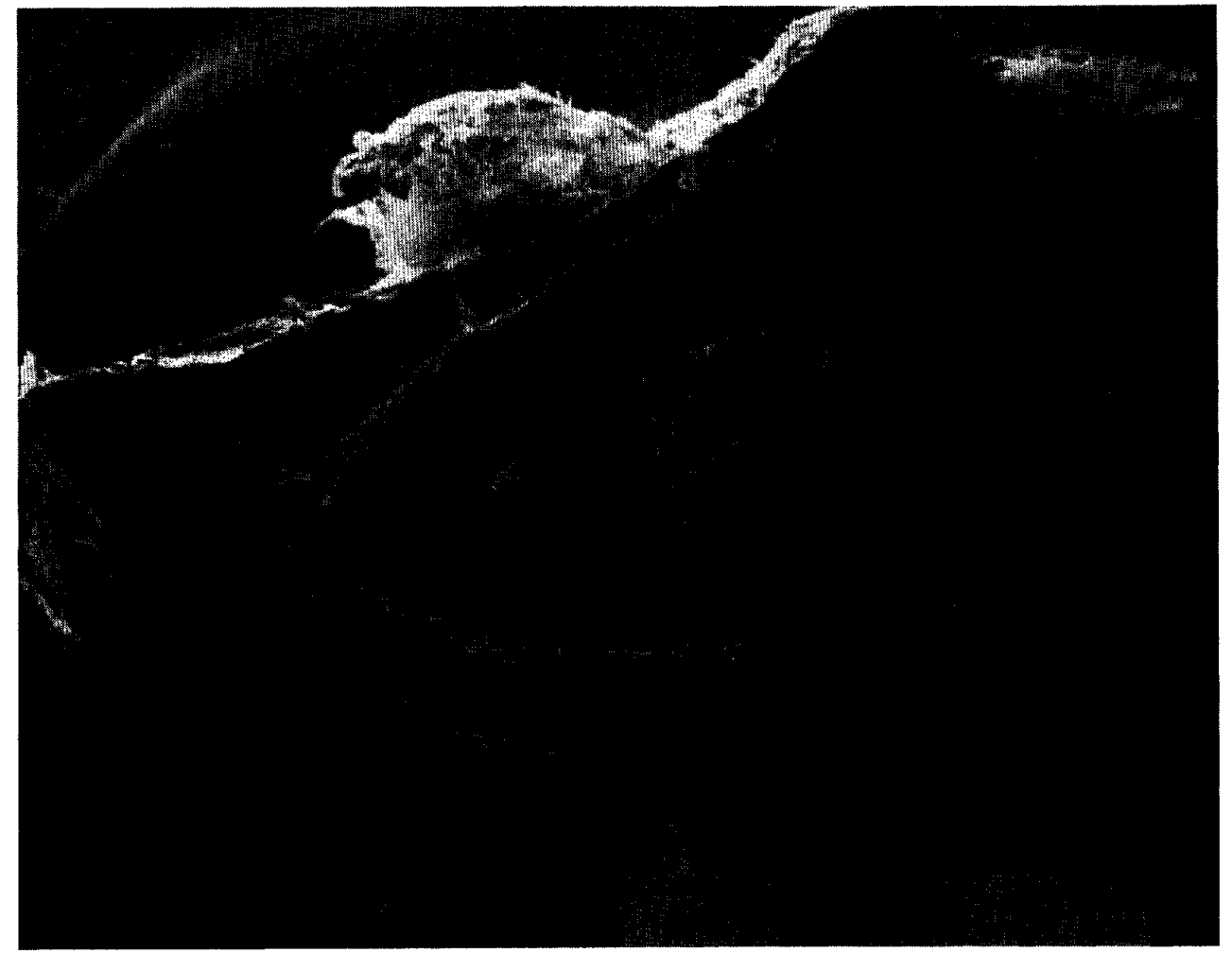

Fig. 31 Alveolar bone of the 6 th week. Control group (SEM)

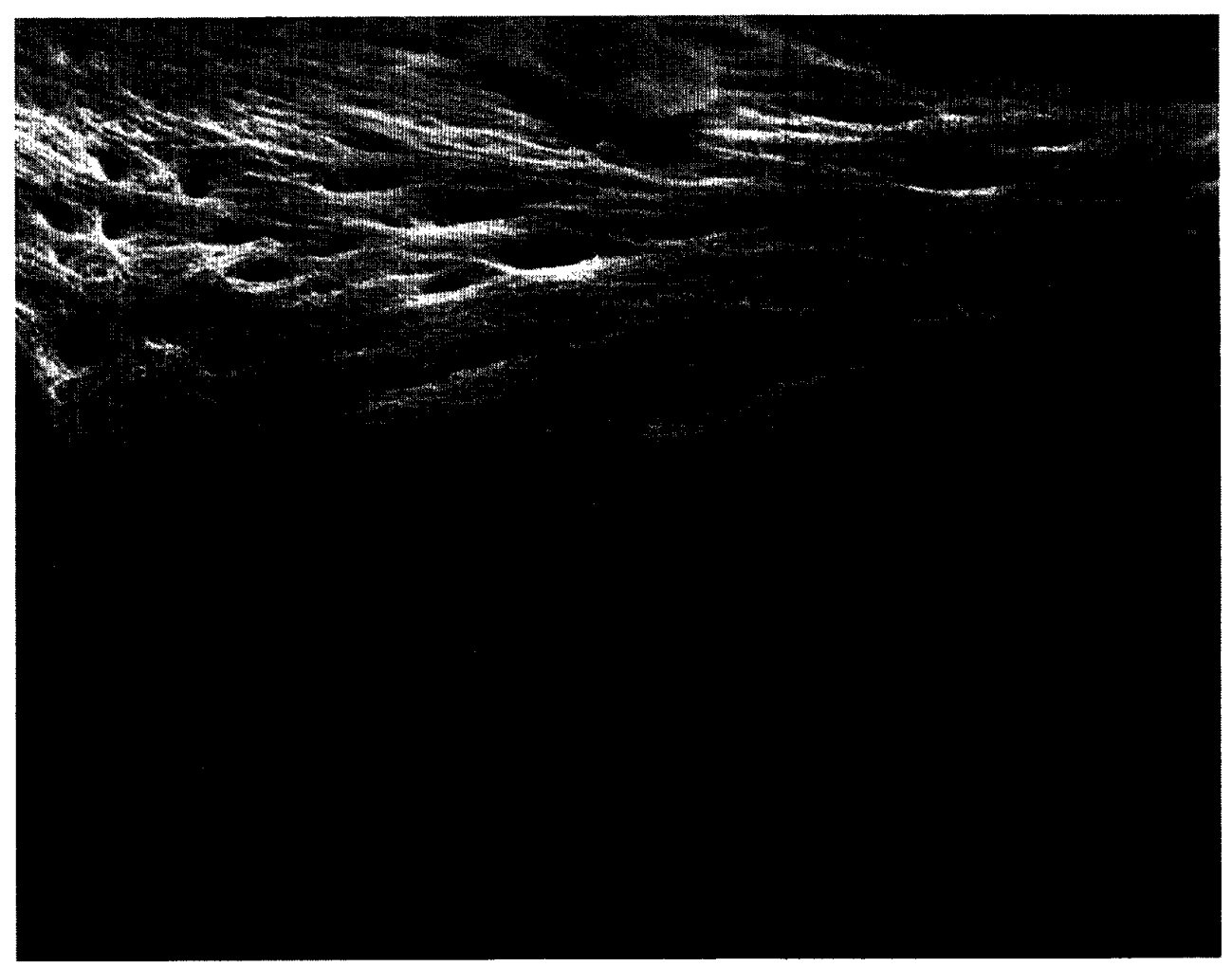

Fig. 32 A higher magnification of Fig. 33. (SEM) 




Fig. 33 Alveolar bone of the 6 th week. Non-Ca diet, high-Ca diet and ECT group (SEM)

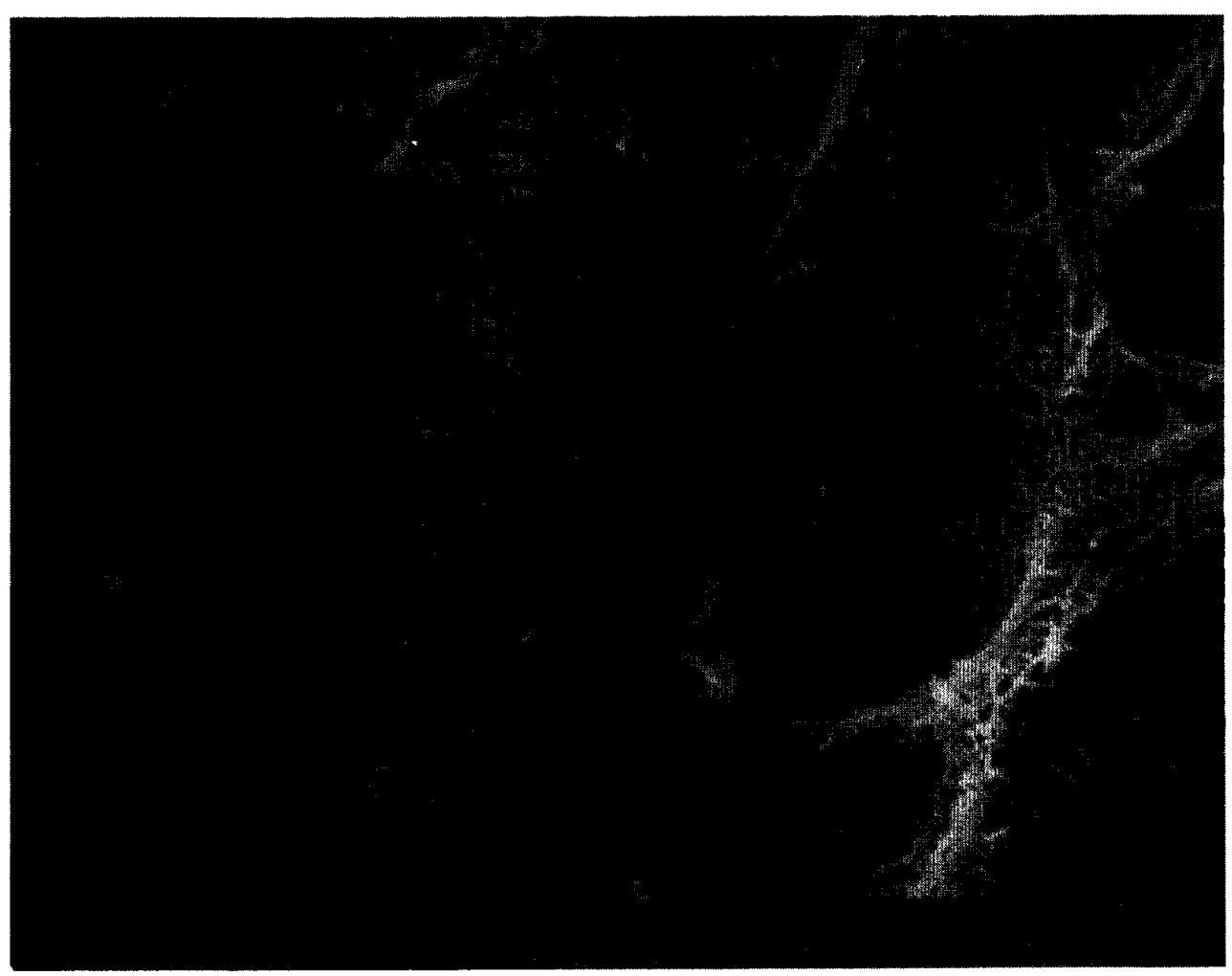

Fig. 34 A higher magnification of Fig. 33. (SEM) 


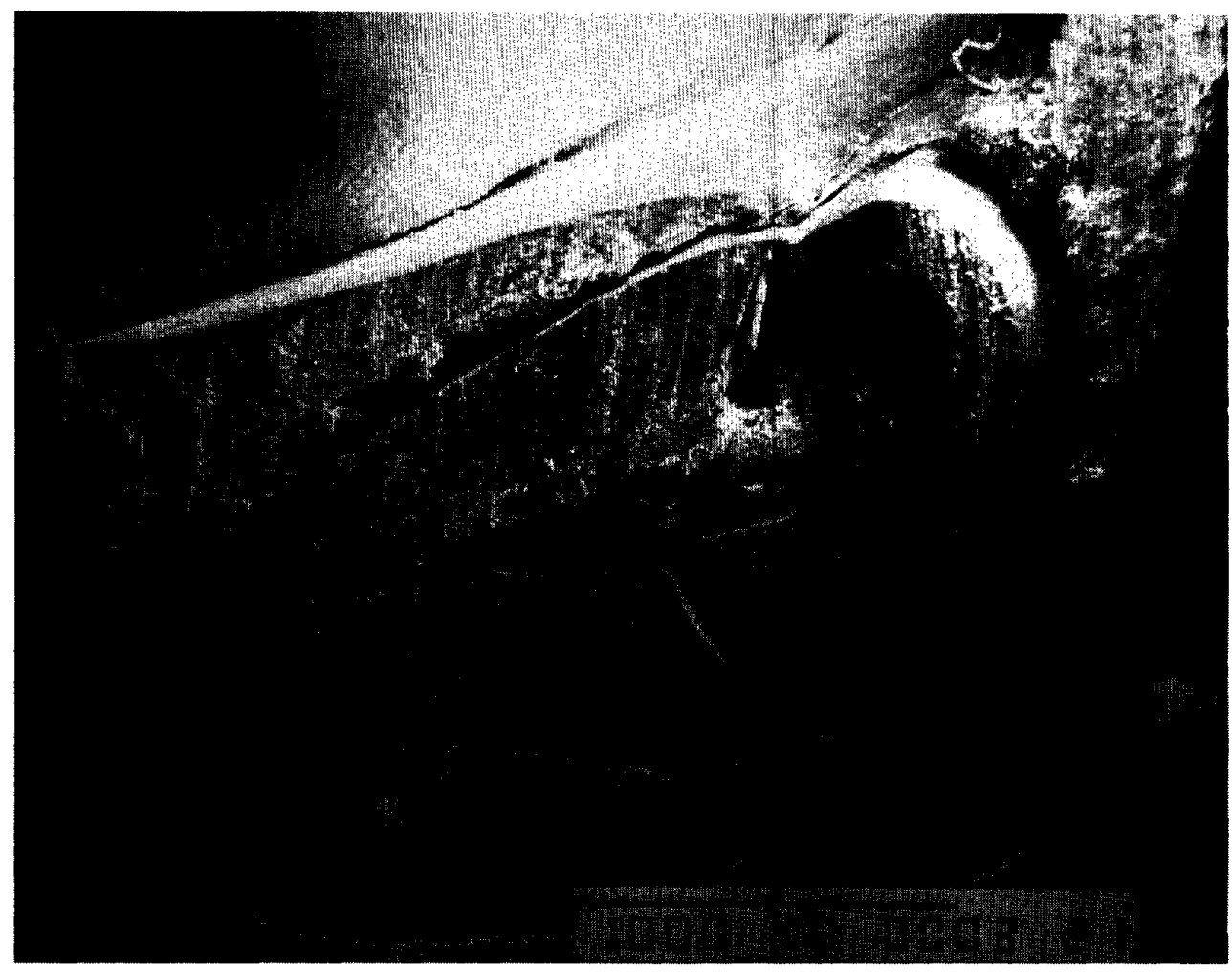

Fig. 35 Alveolar bone of the 6 th week. Low-Ca diet and standard diet group (SEM)

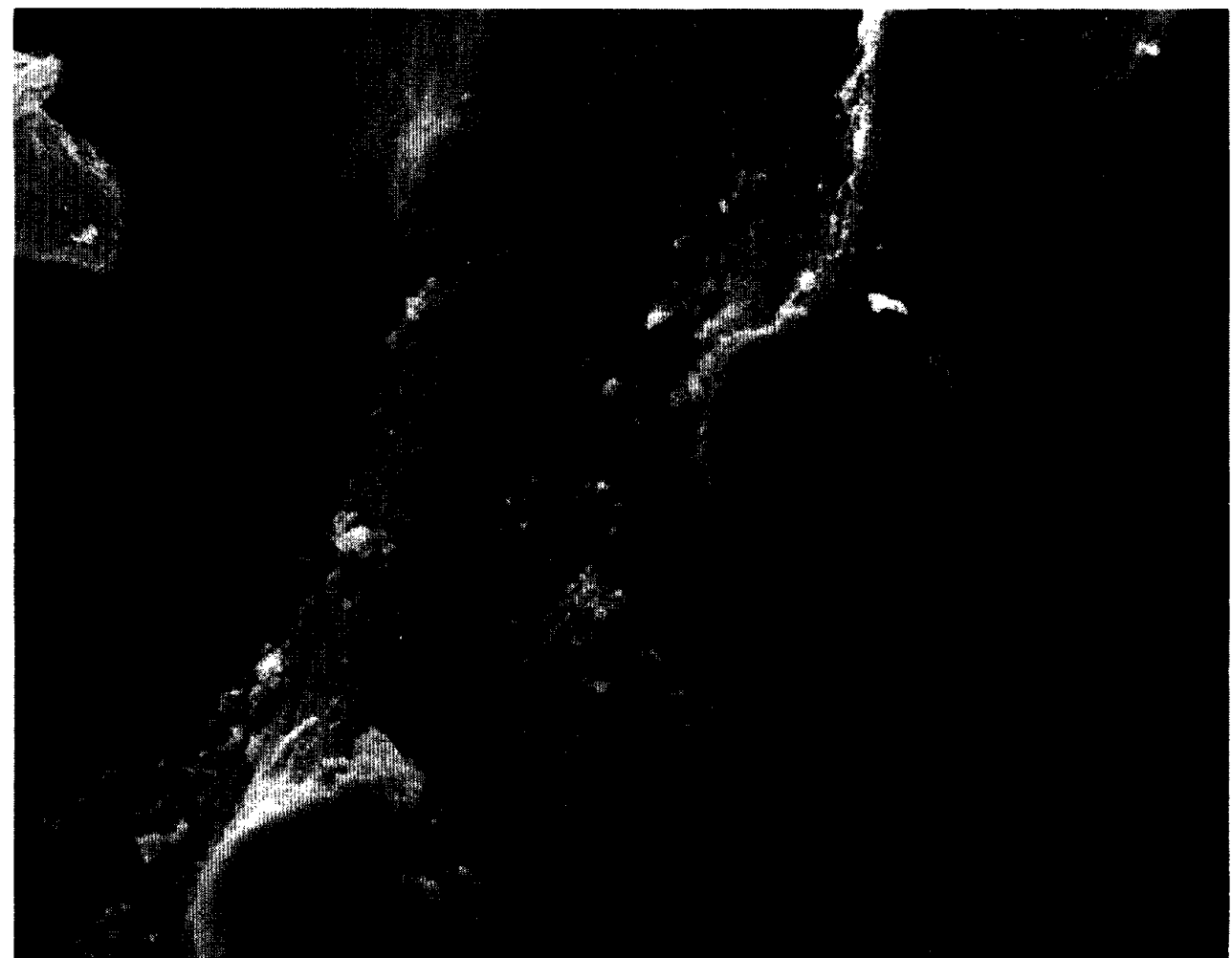

Fig. 36 A higher magnification of Fig. 35. (SEM) 


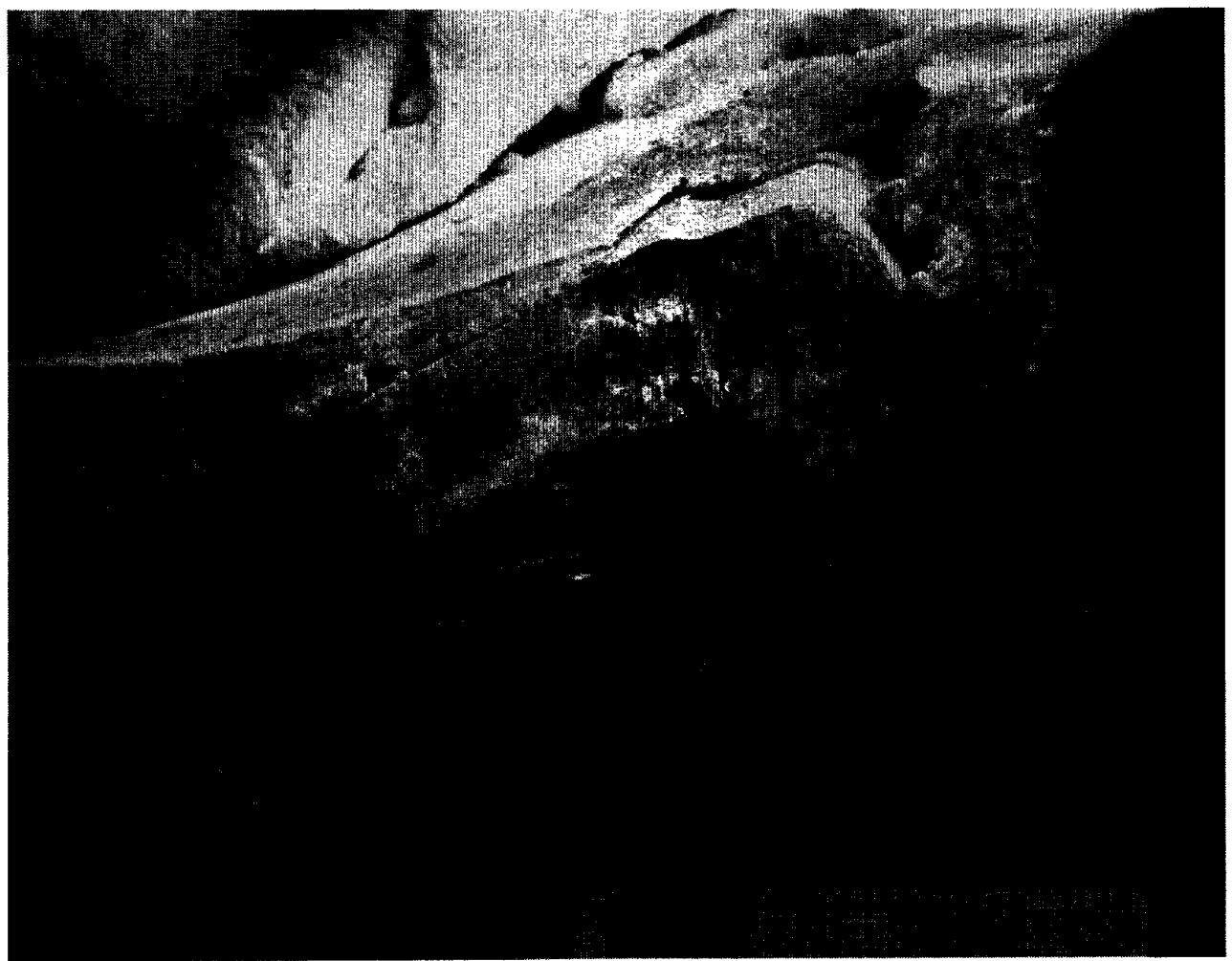

Fig. 37 Alveolar bone of the 6 th week. Low-Ca diet, high-Ca diet and ECT group (SEM)

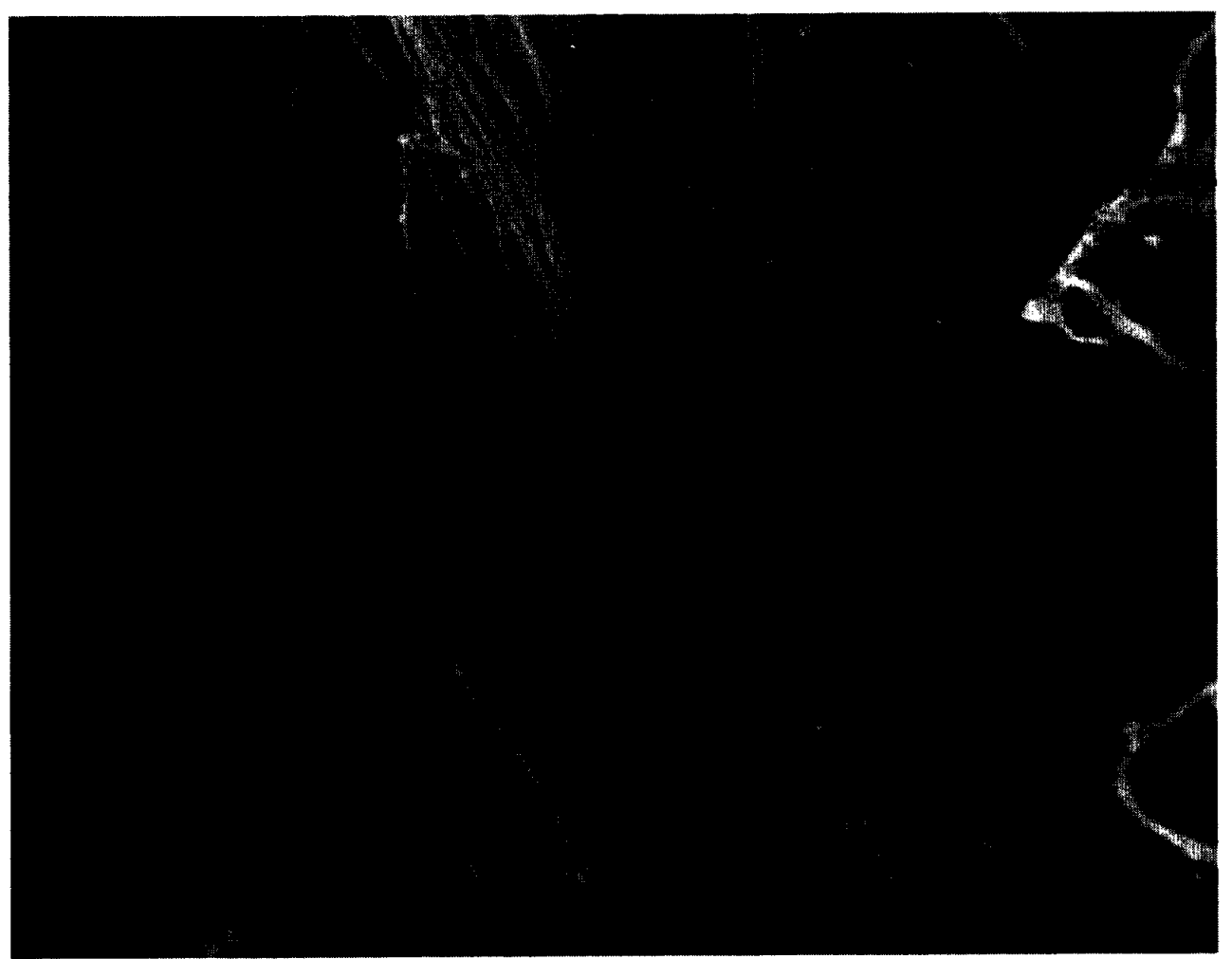

Fig. 38 A higher magnification of Fig. 37. (SEM) 
Table 5 Laboratory values of electrolytes

\begin{tabular}{|c|c|c|c|c|c|c|c|c|}
\hline \multirow[b]{2}{*}{ Electrolyte } & \multicolumn{2}{|c|}{ Control group } & \multicolumn{2}{|c|}{$\begin{array}{l}\text { Non-Ca diet, } \\
\text { high-Ca diet } \\
\text { and ECT group }\end{array}$} & \multicolumn{2}{|c|}{$\begin{array}{c}\text { Low-Ca diet and } \\
\text { standard diet } \\
\text { group }\end{array}$} & \multicolumn{2}{|c|}{$\begin{array}{l}\text { Low-Ca diet, } \\
\text { high-Ca diet } \\
\text { and ECT group }\end{array}$} \\
\hline & Mean & S.D. & Mean & S.D. & Mean & S.D. & Mean & S.D. \\
\hline $\mathrm{Ca}(\mathrm{mg} / \mathrm{d} \ell)$ & 10.38 & 0.24 & 10.36 & 0.42 & 10.53 & 0.16 & $10.75^{* *}$ & 0.09 \\
\hline $\mathrm{P}(\mathrm{mg} / \mathrm{d} \ell)$ & 7.66 & 0.40 & $8.90^{* *}$ & 0.92 & $8.88 * *$ & 0.43 & $10.20 * *$ & 0.47 \\
\hline $\mathrm{Ca} / \mathrm{P}$ & 1.36 & 0.07 & $1.19 * *$ & 0.14 & $1.19 * *$ & 0.06 & $1.06 * *$ & 0.05 \\
\hline $\mathrm{Na}(\mathrm{mEq} / \ell)$ & 142.88 & 1.05 & $141.25^{*}$ & 1.48 & $145.13^{* *}$ & 0.78 & 141.75 & 0.97 \\
\hline $\mathrm{K}(\mathrm{mEq} / \ell)$ & 5.10 & 0.42 & $5.74^{*}$ & 0.53 & $5.60^{*}$ & 0.28 & $5.51^{*}$ & 0.30 \\
\hline $\mathrm{Cl}(\mathrm{mEq} / \ell)$ & 102.88 & 1.83 & 103.63 & 1.58 & 102.63 & 0.99 & $100.25^{* *}$ & 1.20 \\
\hline
\end{tabular}

Table 6 Laboratory values of blood chemistry

\begin{tabular}{|c|c|c|c|c|c|c|c|c|}
\hline \multirow[b]{2}{*}{ Substance } & \multicolumn{2}{|c|}{ Control group } & \multicolumn{2}{|c|}{$\begin{array}{l}\text { Non-Ca diet, } \\
\text { high-Ca diet } \\
\text { and ECT group }\end{array}$} & \multicolumn{2}{|c|}{$\begin{array}{l}\text { Low-Ca diet and } \\
\text { standard diet } \\
\text { group }\end{array}$} & \multicolumn{2}{|c|}{$\begin{array}{l}\text { Low-Ca diet, } \\
\text { high-Ca diet } \\
\text { and ECT group }\end{array}$} \\
\hline & Mean & S.D. & Mean & S.D. & Mean & S.D. & Mean & S.D. \\
\hline GOT (U) & 144.38 & 10.10 & $199.88 * *$ & 35.66 & $241.75^{* *}$ & 58.24 & $182.25^{* *}$ & 23.45 \\
\hline GPT (U) & 32.38 & 4.55 & $41.88^{* *}$ & 6.29 & $43.13^{* *}$ & 8.04 & 35.88 & 3.06 \\
\hline LDH（U） & 1004.38 & 161.65 & 1174.75 & 177.33 & $2396.25 * *$ & 434.65 & $1342.13^{*}$ & 262.55 \\
\hline CPK (U) & 1848.13 & 222.10 & $2481.38 *$ & 545.26 & $5561.25 * *$ & 2400.41 & $2908.50 * *$ & 502.91 \\
\hline ALP (U) & 200.63 & 27.91 & 234.25 & 37.88 & $250.13^{*}$ & 44.71 & 181.75 & 48.27 \\
\hline
\end{tabular}

ウム食・ECT 群は1342.13U だった．同様の検定では， 低カルシウム食・標準食群の間に $1 \%$ ，低カルシウム 食・高カルシゥム食・ECT 群の間に $5 \%$ の危険率で有 意差が認められ, 対照群が低值だった。

4. $\mathrm{CPK}$

対照群の平均 CPK 值は $1848.13 \mathrm{U}$ ，カルシゥム欠乏 食・高カルシウム食·ECT 群は2481.38U, 低カルシウ ム食・標準食群は5561.25U, 低カルシゥム食・高カルシ ウム食・ECT 群は2908.50U だった．同様の検定では， 低カルシウム食·標準食群, 低カルシゥム食・高カルシ ウム食・ECT 群の間に $1 \%$ ，カルシゥム矢乏食・高カ ルシウム食·ECT 群の間に $5 \%$ の危険率で有意差が認 められ，対照群が低值であった。

5. ALP

対照群の平均 ALP 值は200.63U，カルシウム欠乏
食·高カルシゥム食·ECT 群は234.25U, 低カルシウム 食・標準食群は250.13U, 低カルシウム食・高カルシウ ム食·ECT 群は181.75Uだった．同様の検定では，低 カルシゥム食・標準食群の間に $5 \%$ の危険率で有意差 が認められ，対照群が低値だった（Table 6).

\section{考实}

骨組織では，分化が完了した後む，絶えず吸収と形成 を通じて改造現象が起こり，骨組織自身の更新と，体内 のカルシウム・リン酸の調節が行われる28. 分化が完了 した骨組織では, カルシウム摄取量が所要量に達してい れば，骨吸収量と骨形成量は平衡状態を保つことができ るが, 達していなければ, 血中 $\mathrm{Ca}$ 濃度は低下傾向を示 し, 骨の他にも血液・神経·筋・内分泌系等に重大な影 響を及ぼすことになる。この時骨組織では，形成量が減 
少するだけでなく吸収量は増加し，積極的にカルシウム を血中へ動員して徐々に虚弱状態に陥るとされている.

この様に, 骨組織がカルシゥムの貯蔵庫として恒常性 維持機構確立の為の重要な役割を果たしていることは, 様々な動物実験 ${ }^{(-35)}$ により解明されてきた。ただしこれ らの実験は，摂取量が所要量の $10 \%$ 未満という極度の カルシウム欠乏状態で虚弱骨を惹起しており, in vivo での環境に程遠いことは否めない，また，成長期でのカ ルシゥム欠乏状態が惹起した虚弱骨に対する様々な実験 的治療が，いずれも高い効果を発揮しつつも完全な回復

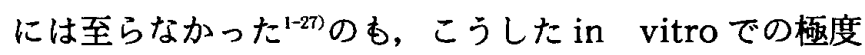
のカルシゥム欠乏状態に起因するものと推測される.

そこで著者は，より多量のカルシウムを撖取しながら カルシゥム欠乏状態に宿るような30\% 低カルシウム飼 料を調製した。 この $30 \%$ 低カルシウム飼料で惹起され た虚弱歯槽骨と, 従来のカルシゥム欠乏飼料で惹起され た虚弱歯槽骨の二種に対して高カルシゥム食と ECT の 併用療法が及ぼす影響について検索したので考察する.

I. 体重

石井 $(1986)^{19)}$ は，カルシゥム欠乏食を与えられた ラットでは, 実験 1 週目までは対照群とカルシゥム欠乏 食群の体重はほぼ同様に増加しているが， 2 週目になる と実駼群は逆に減少し，その後は緩慢に増加するが対照 群との差は大きくなっていくとし，梅津 (1991) ${ }^{4)}$ は, 生後 3 週龄のラットに 3 週間カルシウム欠乏食を与えそ の後正常食で飼育した群と高カルシゥム食で飼育した群 とを比較する実験において，カルシウム欠乏食群・標準 食群, カルシゥム欠乏食群・高カルシウム食群とも対照 群よりは低值に推移したが，カルシゥム欠乏食・高カル シゥム食群の方がカルシゥム欠乏食・標準食群より高值 で推移したと述べている.また, 内野 $(1991)^{16)}$ の $\mathrm{ECT} \cdot$ 活性型ビタミン $\mathrm{D}_{3}$ の併用療法の実験でも, カル シゥム欠乏食・標準食・ECT ・ 活性型ビタミン $\mathrm{D}_{3}$ 群の体 重は実験 5 週目までは依然として対照群の值には及ばな かった．著者の実験で，カルシゥム欠乏食・高カルシゥ ム食·ECT 群, 低カルシウム食・標準食群が実験期間中 に対照群に追いつくことができず，前者の方が後者より 低值で推移したのは，骨から血中へのカルシウム動員量 の差に由来すると推測される. また，標準食を用いた群 より高カルシウム食と ECT を併用した群の方が回復効 果が高かったのも注目すべき結果であり, 骨の回復程度 の差を示唆している. しかし, 低カルシゥム食・高カル シウム食・ECT 群が実験 4 週目より対照群より高值で 推移したことから直ちに対照群より高い骨構築を結論付
けることはできない. Salomon (1972) ${ }^{29)}$ が言うよう に, 骨組織の増減により体重の増減が引き起こされるこ とは十分考えられるが，骨形成に付随する筋組織やその 他の組織の形成発達す無視できず，体重増減の本態をこ の結果だけから判断することはできない，しかし，カル シゥム欠乏状態が原因の体重減少に対して, 高カルシウ 么食と ECT の併用療法が効果的なことは明らかとなっ た.

\section{II. $\mathrm{X}$ 線学的所見}

石井 $(1986)^{199}$ は，カルシウム欠乏食を与えられた ラットでは実験 3 週目に歯槽骨の骨密度が減少し, 骨梁 の減少と配列の乱れが見られ，5週目まで低濃度で，骨 梁は疎ではあるが太くなると述べている，住本ら（1985 )$^{20)}$ は, 生後 3 週齢のラットに 3 週間カルシウム欠乏食 を与えその後正常食で飼育した実験において，歯槽骨の 厚さは増加し骨梁の数は増えてより緻密に配列し, 虚弱 骨の改善が見られたと指摘している. 本実験む，低カル シウム食・標準食群は対照群に比べ蒾槽骨の厚さ之数密 さでは劣り，一旦虚弱状態に陥った歯槽骨は正常食だけ では完全には回復しにくいことを示している。 そこでカ ルシゥムの増量に着目すると，木村ら $(1987)^{21)}$ のカル シウム久乏食の後, 標準食とイワシパウダーの混合食を 与えた実験では, 歯槽骨の X 線学的所見で実験 8 週目 に骨梁が増加し, 黄本 $(1990)^{3)}$ も同様の実験で, 日数 の経過と共に骨梁がより多くなり緻密に配列したことを 認めた．梅津 (1991) ${ }^{4}$ は，イワシパウダーの代わりに 今回著者が用いた牛骨粉を応用したが，カルシウム欠乏 食・高カルシゥム食群においてやはり骨の石灰化と骨梁 形成が促進されたと述べている. ECT の効果に関して 鯵坂 $(1988)^{7)}$ は，カルシゥム欠乏食で飼育されている ラットにECT を投与したところ，歯槽骨は薄く骨梁は 少なく配列しているが，カルシウム欠乏食群より歯槽骨 は厚く骨梁も多く見られたと述へ，新城 $(1988)^{8)}$ は， 正常食で飼育されているラットにECT を投与した結 果, 骨梁は対照群より緻密になったと報告している．本 実験では，虚弱骨に対して高カルシウム食とECT を投 与したが, 正常食単味を応用した群よりあ歯槽骨は厚く なり骨梁も增加して緻密に配列し, 高カルシウム食と ECT の併用療法は虚弱骨に対して X 線学的に高い効果 を示すと考えられる.

\section{X 線学的骨密度（骨塩量）}

石井 (1986) ${ }^{19)}$ は，カルシゥム欠乏食性骨粗䉘症の実 験において, 実験群の歯槽骨の骨密度が対照群より低 かったと述べている. 黄本 $(1990)^{3)}$ は, 実験 8 週目か 
らは高カルシウム食群の方が対照群より骨密度は高かっ たと述べている，一方 ECT について新城 $(1988)^{8)}$ は, ECT 投与 3,4 週目では実験群の骨密度は対照群より高 かったと報告している，著者の実験で屯，虚弱骨に対し て高カルシゥム食と ECT の併用療法の方が標準食単味 より骨密度が増加することが分った。この結果は低カル シウム食による虚弱骨で認められたものの， 3 週間の応 用では対照群の值までには回復しなかった。したがっ て, 虚弱骨の骨密度を回復させるのに高カルシウム食と ECT の併用療法が勃果的なことは示唆されたが，その 応用期間に関しては今後更に検討すべきである。

\section{IV. 定性·定量分析所見}

面分析に関して陳 $(1989)^{1)}$ は，同一骨梁の範囲内で は $\mathrm{Ca}$ の特性 X 線像は，対照群でも実験群でも $\mathrm{P}$ に比

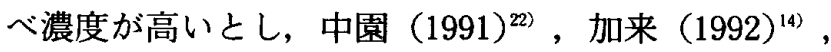
首藤 $(1992)^{23)}$, 坂本 $(1994)^{24)}$ らも同様の所見を得た. 著者の実験です，骨虚弱状態やその回復過程であ Ca と $\mathrm{P}$ の組成は変化しないことが分った．点分析の結果で も，全ての群で $\mathrm{Ca}$ と $\mathrm{P}$ の比はほぼ一定で有意差はな く，骨組織の組成自体には異常が認められなかった。

V. 光学顕微鏡所見及び走查型電子顕微鏡所見

石井 $(1986)^{19)}$ は，カルシウム欠乏が歯槽骨の歯根膜 に接する部分での骨吸収を促し，吸収層の表面での骨芽 細胞の出現を抑え，低石灰化層を増加させたと述べてい る。一度虚弱化した歯槽骨に対して高カルシウム食を応 用し，黄本 $(1990)^{3)}$ はハバース管と骨小腔の増加を， 梅津 (1991) $)^{4)}$ は破骨細胞の減少, 骨梁の活発な形成, 層板骨の形成を認めたが，中河原 $(1992)^{5)}$ は，高カル シゥムの長期間の摄取が腸管での吸収能を低下させ骨芽 細胞によるコラーゲン原線維の産生や石灰化を阻害する と述べている，一方 ECT を用いた鯵坂 $(1988)^{7)}$ は八 バース管と骨小腔の増加や破骨細胞と吸収骷の減少を認 め，また，木村 $(1991)^{9)}$ あ同様の所見を得，ECT の骨 吸収抑制作用之骨形成促進作用を確かめ大。坂本（1994 ） ${ }^{24)}$ は，標準食と ECT の併用療法の方が標準食単昧よ りハバース系が増加したと述べている．今回の実験では 高カルシゥム食と ECT を併用し，標準食単味より高い 骨構築所見を得た。これは ECT の血清 $\mathrm{Ca}$ 低下作用が 優位に働き，高カルシウム摄取状況です腸管でのカルシ ウム吸収能が低下しなかったためと考えられる．従っ て，虚弱骨に対する高カルシウム食と ECT の併用療法 は骨の再構築において病理組織学的に有効なことが示唆 された。

VI. 血液所見

\section{A. 電解質検査}

血清 $\mathrm{Ca}$ 值で対照群と低カルシウム・高カルシウム． ECT 群の間に有意差が認められたが, 全ての値は木村 ら (1992 $)^{37)}$ の正常值範囲内だった. Albright ら $(1940)^{38)}$ や真田 $(1966)^{39}$ らは骨粗鬆症の血液所見の 特徽は, 血清 $\mathrm{Ca}$, 血清 $\mathrm{P}$ の值が正常なことだと述べて いるが，著者の実験でもこれに合致した所見が得られ， 血中 $\mathrm{Ca}$ 濃度がカルシゥム欠乏状態です一定に保たれる ことが裏付けられた。 その他異常は認められない。

B. 生化学検查

今回の実験では, カルシゥム欠乏食・高カルシウム 食·ECT 群, 低カルシウム食・標準食群, 低カルシウム 食·高カルシウム食·ECT 群とも対照群と比へ， GOT と GPT が上昇傾向にあり肝機能の低下が引き起こされ た可能性がある。 また低カルシウム食を用いた 2 群では LDH と CPK が同時に上昇傾向を示したことで心筋へ の影響が示唆された。 また，ALPは低カルシウム食． 高カルシゥム食・ECT 群以外が対照群と此べ高值を示 し，真田 (1966) $\left.{ }^{39}\right)$ の骨粗鬆症に関する報告に合致し た.

全ての結果から, 成長期の虚弱骨において, 高カルシ ウム食と ECT の併用療法が骨構築を促進し高い効果を 示すことが分った．陳 (1989) ${ }^{1}$ ， 木村ら $(1989)^{2)}$ ，黄 本 $(1990)^{3)}$ ，梅津 $(1991)^{4)}$ らが虚弱骨に対する高カル シゥム食の有用性を認める一方で，中河原 $(1992)^{5)}$ は, 長期に及ぶ投与期間が，腸管でのカルシゥム吸収能の低 下を招き骨構築に逆効果であることを示唆した。 しか し，今回の実験では，ECT と併用し標準食単味より高 い効果を得ることができた．松本ら（1988）年）の報告に みられるように ECT は破骨細胞に作用し, 骨塩溶解を 抑制する一方，腎近位尿細管における活性型ビタミン $\mathrm{D}_{3}$ 産生を高める。活性型ビタミン $\mathrm{D}_{3}$ の作用は細胞の分 化誘導, 免疫調節など多披に渡るが, 最も重要な作用は 腸管からのカルシウム吸収の促進之腎遠位尿細管でのカ ルシウム再吸収の促進で，このことが腸管でのカルシウ ム吸収能の低下を阻害したと推測される.

\section{結 論}

生後 3 週齢のウィスター系雄ラットにカルシウム欠乏 食や低カルシゥム食を投与し虚弱歯槽骨を惹起させ，高 カルシウム食と ECT の併用療法による骨構築の促進作 用を検索したところ, 次のような結果を得た。

1. 体重

低カルシウム食・高カルシウム食・ECT 群は対照群よ 
り高値まで回復したが, その他の群は低值だった。

2. X 線学的所見

対照群に比べ他の群では, 骨梁は減少し配列も不規則 だったが，歯槽骨の骨構築状態はかなり改善された.

3.X 線学的骨密度（骨塩量）

骨密度の平均 $\mathrm{Al}$ 当量は対照群が最も高く，次いで低 カルシウム食・高カルシウム食·ECT 群, 低カルシウム 食・標準食群, カルシウム欠乏食・高カルシウム食 ECT 群の順だった。

\section{4. 定性·定量分析所見}

全ての群において，歯槽骨の同一骨梁内における特性



\section{5. 光学顕微鏡所見}

対照群と比ベカルシウム欠乏食・高カルシウム食・ ECT 群, 低カルシウム食・標準食群は骨吸収が顕著で 骨量の減少が認められた。低カルシウム食・高カルシウ ム食・ECT 群は対照群に次いで骨構築が促進されてい た.

\section{6. 走查型電子顕微鏡所見}

対照群と比ベカルシウム欠乏食・高カルシウム食 · ECT 群，低カルシウム食・標準食群では骨䯣の拡大と， 広範な骨吸収所見が認められた。低カルシウム食・高力 ルシゥム食・ECT 群は, 形態的には対照群とほぼ同様 な所見を呈していた。

7. 血液所見

電解質検査では異常が認められなかったが，生化学検 查では一部異常が認められた.

以上の結果から，虚弱骨に対する高カルシウム食と ECT の併用療法は，骨の石灰化度と骨構築に関し標準 食単味より高い効果を示すことが明らかとなり，臨床で の応用が期待できることが示唆された。

稿を終わるに当たり，日夜を問わず終始根切なる御指 導と御校閲の労を睗りました恩師木村光孝教授に深甚な る敬意と感謝の意を捧げます。また，実験に御協力頂い た九州歯科大学小児歯科学教室の各位にお礼を申し上げ ます。

\section{引用文献}

1) 陳 溢宮：成長期額骨とカルシウム摄取に関する実験的研 究一とくに下頕頭の変化一. 九州雬会誌 $43: 710-745$, 1989.

2 ）木村光孝, 西田郁子, 牧 憲司, 横本 満, 曾我富美雄, 尾崎章寿，古谷充朗，高橋宙丈：成長期顎骨の実験的骨粗 犎症に対する高カルシウム食の影響に関する研究一とくに
歯槽骨の変化一。 九州雪会誌 $43: 778-801,1989$.

3) 黄本恒裕：実験的骨粗髢症に対するカルシウムの影響に関 する X 線学的ならびに病理組織学的研究一とくに成熟期 の歯槽骨一。杂州菌会誌 $44: 556-581,1990$.

4) 梅津哲夫：虚弱骨に対する高カルシウム食の影響に関する $\mathrm{X}$ 線的, 光顕的および走查電影的研究一雬槽骨の変化一. 九州菊会誌 $45: 629-652,1991$.

5 ）中河原哲朗：虚弱下㴿骨に対するカルシウム療法に関する 病理組織学的および超微形態学的研究一とくに骨基質形成 一。州萮誌 $46: 764-781,1992$.

6) 橋本敏昭：カルチトニンの成長期顎骨に及ぼす影響に関す る実験的研究一とくに下顎頭の变化一，九州歯会誌 41 ： $886-915,1987$.

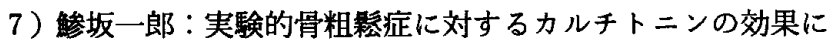
関する研究一とくに歯槽骨の変化一，九州歯会誌 42 ： $523-558,1988$.

$8 ）$ 新城啓和：カルチトニンの成長期買骨に及ぼす影響に関す る実験的研究一之くに荬槽骨の变化一. 九州歯会誌 42 : $648-688,1988$.

9）木村光孝：カルシウム不足の成長期䫟骨に対する生理活性 物質の応用に関する透過型電顕的研究一とくに下䫇頭の变 化一. 平成 2 年度歯科大学研究助成金研究成果報告書, 九 州地区歯科医師会連合会, 福岡, 1991， 1-16.

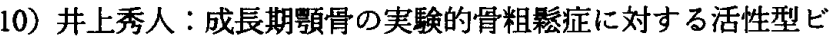
タミン $\mathrm{D}_{3}$ の影響に関する研究一之くに歯槽骨の変化一. 九州歯会誌 $42: 918-948,1988$.

11）岩永典人：実験的骨粗箖症に対する活性型ビタミン $\mathrm{D}_{3}$ の 影幚に関する X 線的，光顕的ならびに電顕的研究一之く に成長期下顎頭の変化一. 九州蒾会誌 $43: 226-262$, 1989.

12）大倉秀一郎：ビタミン D の成長期下買頭に及ぼす影響に 関する実験的研究. 九州菌会誌 $44: 1-38,1990$.

13）高野 治：虚弱骨に対する生理活性物質の影響に関する $\mathrm{X}$ 線的, 光顕的ならびに電顕的研究一とくに下顥頭の变 化一. 九州䨑会誌 $44: 890-919,1990$.

14）加来弘志：虚弱骨に対するカルシウム含有食, 活性型ビタ ミン $\mathrm{D}_{3}$ の併用療法に関する実験的研究. 九州菌会誌 $46: 462-481,1992$.

15）金城 敬：虚弱骨に対するカルシウム，生理活性物質の併 用療法に関するX 線的, 光顕的ならびに電顕的研究一之 くに下䫓頭の変化一，九州䨑会誌 $45: 143-174,1991$.

16）内野公一：虚弱骨に対する生理活性物質の併用療法に関す る実験的研究一とくに歯槽骨の変化一，九州菌会誌 45 ： $425-445,1991$

17）稲川祐成：虚弱骨に対するカルシトニン, 活性型ビタミン $\mathrm{D}_{3}$ の併用療法に関する光顕的ならびに電顕的研究一下顎 頭の変化一, 九州菌会誌 $46: 140-175,1992$.

18）木村光孝, 牧 憲司, 稲川祐成, 渡辺 博, 若杉淳二郎, 曽我富美雄, 横本 満, 矢野目鎮照, Raymond $\mathrm{L}$. Braham：カルシウム不足の成長期下䅡頭に対するカルシ トニン, 活性型ビタミン $\mathrm{D}_{3}$ の併用療法. 小坚歯誌 30 : $69-79,1992$.

19）石井貴三男：成長期顎骨における実験的骨粗堭症に関する 
研究一とくに歯槽骨について一. 九州歯会誌 $40: 530-$ $554,1986$.

20）住本和孝, 木村光孝, 楊榮展：実験的骨粗鬆症に対する食 餌療法に関する研究一特に雬槽骨について一，小児歯誌 $23: 271-272,1985$.

21）木村光孝, 内野公一, 佐藤秀輝, 竹中正史, 原田和巳, 栗 生 语：カルシゥムの成長期頡骨に及ぼす影響に関する $\mathrm{X}$ 線学的検索. 小児歯誌 $25: 521-530,1987$.

22）中園志保：顎骨の成長に関するX 線的, 光顕的ならびに 走查電顕的研究一食物の硬軟による下顎頭の変化一，九州 霜会誌 $45 ： 1-23,1991$.

23）首藤洋治：顎骨の成長に関するX $\mathrm{X}$ 線的，光顕的ならびに 走查電顥的研究一食物の硬軟による茵槽骨の変化一，九州 歯会誌 $46: 574-595,1992$.

24）坂本淑子：虚弱下䫑頭に対するカルシウム, カルシトニン の併用療法に関する光顕的ならびに超微形態的研究. 九州 歯会誌 $48 ： 6-28,1994$.

25）中尾利夫 : 成長期顎骨における実験的骨粗叞症に関する研 究一之くに下顎頭の变化一, 九州歯会誌 $41: 46-67$, 1987.

26）篠崎英一：実験的骨粗豦症に対する食餌の影響に関する研 究一とくに下顎頭の変化一. 九州歯会誌 $41: 102-121$, 1987.

27）木村光孝, 西田郁子, 牧 憲司, 加来昭典, 矢野目鎮照, 高橋宙丈，松田容士子：虚弱骨に対する食餌の影響に関す る研究一とくに下顎頭の変化一。少菌誌 $28: 949-$ $955,1990$.

28) Liu, C. C. and Baylink, D. J. : Differential response in alveolar bone osteoclasts residing at two different bone sites. Calcif. Tissue Int. $36: 182-188,1984$.

29) Salomon, C. D. : Osteoporosis following calcium deficiency in rats. Calcif. Tissue Res. $8: 320-333,1972$.
30）松本文博：低カルシゥム食飼育成長期ラットにおける下顎 頭軟骨の組織学的研究. 四国菌誌 $3: 161-177,1989$.

31）大谷啓一，天野 均，小椋秀亮：低カルシゥム食飼育ラッ トの臼歯部雨槽骨吸収の進行に関する研究。口病誌 59 ： $585-593,1992$.

32) Urist, M. R. and McLean, F. C. : Accumulation of mast cells in endosteum of bone of calcium-deficient rats. A. M. A. Arch. Pathol. $63: 239-251,1957$.

33) Ornoy, A., Wolinsky, I. and Guggenheim, K. : Structure of long bones of rats and mice fed a low calcium diet. Calcif. Tissue Res. 15:71-76, 1974.

34) Sissons, H. A., Kelman, G. J. and Marotti, G. : Mechanisms of bone resorption in calcium-deficient rats. Calcif. Tissue Int. 36:711-721, 1984.

35) Okudoh, M. : Alveolar bone resorption after calcium deficiency in rats. Bull. Tokyo Med. Dent. Univ. 20 : $131-144,1973$.

36) Jowsey, J. and Gershon-Cohen, J. : Effect of dietary calcium levels on production and reversal of experimental osteoporosis in cats. Proc. Soc. Exp. Biol. Med. 116:437-441, 1964.

37）木村光孝, 西田郁子, 尾崎章寿，今村隆子，太田和子，村 田真知子：ラットにおける血液検査測定値に関する加齡的 変動. 小児歯誌 $30 ： 1037-1047,1992$.

38) Albright, F., Bloomberg, E. and Smith, P. H. : Postmenopausal osteoporosis. Trans. A. Amer. Phys. 55 : $298-305,1940$.

39）真田孝三：骨粗鬆症の臨休像. 慈恵医大誌 $80: 617$ $635,1966$.

40）松本俊夫, 尾形悦郎：血清カルシゥム濃度の調節系. Medicina 25:1482-1484, 1988. 